\title{
BK Channels Localize to the Paranodal Junction and Regulate Action Potentials in Myelinated Axons of Cerebellar Purkinje Cells
}

\author{
Moritoshi Hirono, ${ }^{1}$ Yasuhiro Ogawa, ${ }^{3}$ Kaori Misono, ${ }^{2}$ Daniel R. Zollinger, ${ }^{3}{ }^{\oplus}$ James S. Trimmer, ${ }^{4}$ \\ Matthew N. Rasband, ${ }^{3}$ and Hiroaki Misonou ${ }^{1,2}$ \\ ${ }^{1}$ Graduate School of Brain Science, Doshisha University, Kyoto 619-0225, Japan, ${ }^{2}$ Department of Neural and Pain Sciences, Dental School, University of \\ Maryland, Baltimore, Maryland 21201, ${ }^{3}$ Department of Neuroscience, Baylor College of Medicine, Houston, Texas 77030, and ${ }^{4}$ Department of \\ Neurobiology, Physiology, and Behavior, University of California, Davis, Davis, California 95616
}

In myelinated axons, $\mathrm{K}^{+}$channels are clustered in distinct membrane domains to regulate action potentials (APs). At nodes of Ranvier, Kv7 channels are expressed with $\mathrm{Na}^{+}$channels, whereas Kv1 channels flank nodes at juxtaparanodes. Regulation of axonal APs by $\mathrm{K}^{+}$ channels would be particularly important in fast-spiking projection neurons such as cerebellar Purkinje cells. Here, we show that BK/Slo 1 channels are clustered at the paranodal junctions of myelinated Purkinje cell axons of rat and mouse. The paranodal junction is formed by a set of cell-adhesion molecules, including Caspr, between the node and juxtaparanodes in which it separates nodal from internodal membrane domains. Remarkably, only Purkinje cell axons have detectable paranodal BK channels, whose clustering requires the formation of the paranodal junction via Caspr. Thus, BK channels occupy this unique domain in Purkinje cell axons along with the other $\mathrm{K}^{+}$ channel complexes at nodes and juxtaparanodes. To investigate the physiological role of novel paranodal BK channels, we examined the effect of BK channel blockers on antidromic AP conduction. We found that local application of blockers to the axon resulted in a significant increase in antidromic AP failure at frequencies above $100 \mathrm{~Hz}$. We also found that $\mathrm{Ni}^{2+}$ elicited a similar effect on APs, indicating the involvement of $\mathrm{Ni}^{2+}$-sensitive $\mathrm{Ca}^{2+}$ channels. Furthermore, axonal application of BK channel blockers decreased the inhibitory synaptic response in the deep cerebellar nuclei. Thus, paranodal BK channels uniquely support high-fidelity firing of APs in myelinated Purkinje cell axons, thereby underpinning the output of the cerebellar cortex.

Key words: action potential; axon; cerebellum; potassium channel

\section{Introduction}

Voltage-activated ion channels are uniquely situated in myelinated axons of mammalian neurons (Lai and Jan, 2006). Voltageactivated $\mathrm{Na}^{+}$(Nav) channels are localized precisely at the node of Ranvier to generate action potentials (APs). Voltage-activated $\mathrm{K}^{+}(\mathrm{Kv})$ channels are also expressed at and near the node and

Received Sept. 5, 2014; revised March 2, 2015; accepted April 1, 2015.

Author contributions: M.H., M.N.R., and H.M. designed research; M.H., Y.O., K.M., D.R.Z., J.S.T., M.N.R., and H.M. performed research; M.H., Y.O., K.M., D.R.Z., M.N.R., and H.M. analyzed data; M.H., J.S.T., M.N.R., and H.M. wrote the paper.

We thank Drs. Takafumi Miki, Shinya Kawaguchi, Tomoyuki Takahashi, Shoji Watanabe, and Takeshi Sakaba for their technical assistance and critical discussion. This work was supported by NIH grant NS069688 (MNR), NS34383 (JST), Takeda Science Foundation (MH and HM), Naito Foundation (HM), Core-to-Core Program A Advanced Research Networks, and MEXT/JSPS KAKENHI Grant 26640017 (HM).

The authors declare no competing financial interests.

Correspondence should be addressed to either of the following: Hiroaki Misonou, Graduate School of Brain Science, Doshisha University, 4-1-1 Kizugawadai, Kizugawa-shi, Kyoto 619-0225, Japan, E-mail: h_misonou@mac.com; or Matthew Rasband, Department of Neuroscience, Baylor College of Medicine, One Baylor Plaza, Houston, TX 77030, E-mail: rasband@bcm.edu.

Y. Ogawa's present address: Department of Pharmacology, Meiji Pharmaceutical University, Tokyo 204-8588, Japan.

K. Misono's present address: Department of Ophthalmology and Visual Sciences, Kyoto University, Kyoto 6068501, Japan.

DOI:10.1523/JNEUROSCI.3778-14.2015

Copyright $\odot 2015$ the authors $\quad 0270-6474 / 15 / 357082-13 \$ 15.00 / 0$ may regulate axonal APs (Rasband and Shrager, 2000; Devaux et al., 2003; Pan et al., 2006). Among them, Kv7.2/7.3 channels are localized at the node (Pan et al., 2006) and thought to regulate the overall excitability of the nodal membrane (Schwarz et al., 2006). In contrast, Kv1.1/1.2 channels are localized in regions flanking the node called the juxtaparanode (Wang et al., 1993; Rhodes et al., 1997; Rasband et al., 1998). Because this area is covered completely with the myelin sheath, juxtaparanodal Kv1 channels are considered mostly inert under normal conditions (Kocsis and Waxman, 1980) but can be functional during development and when the myelin sheath is retracted in pathological situations, such as multiple sclerosis (Poliak and Peles, 2003; Rasband, 2004). Here, we show that Slo1/BK channels are also found in myelinated axons.

The Slo1/KCa1.1/BK K ${ }^{+}$channel is unique in its coincident activation by changes in membrane potential and intracellular $\mathrm{Ca}^{2+}$ concentration ( $\left[\mathrm{Ca}^{2+}\right]_{\mathrm{i}}$; Salkoff et al., 2006). The BK channel also has an exceptionally large single-channel conductance compared with other $\mathrm{K}^{+}$channels (Salkoff et al., 2006). Therefore, its expression in a specific neuronal compartment, in which BK channels can be exposed to local increases in $\left[\mathrm{Ca}^{2+}\right]_{\mathrm{i}}$, would be expected to significantly affect the local membrane excitability. BK channels are found predominantly in presynaptic termi- 
A

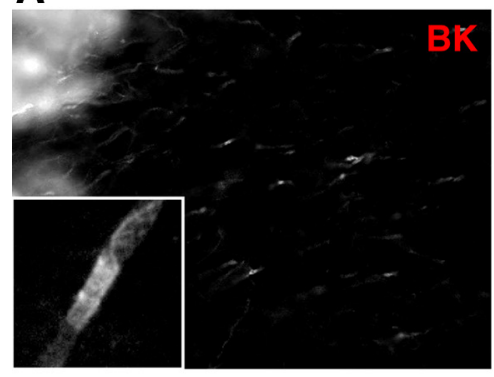

B

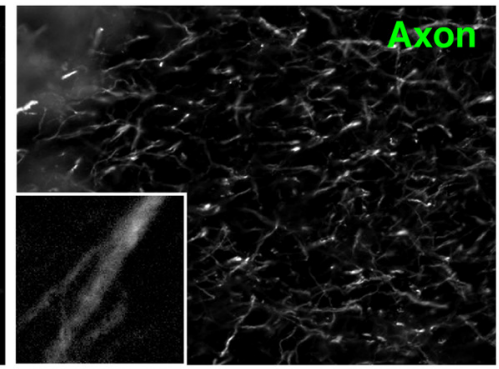

C

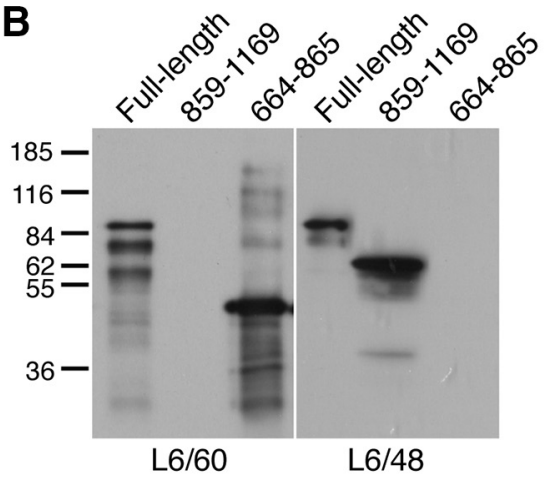

D

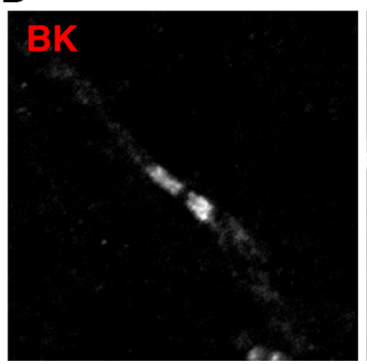

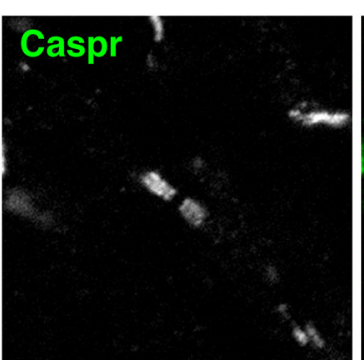
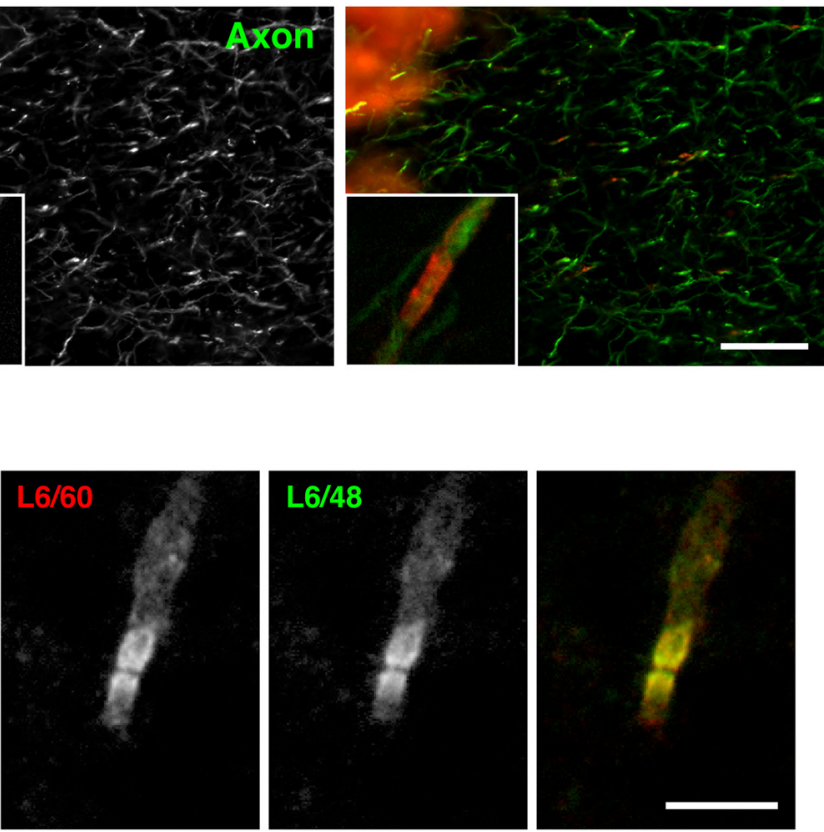

,
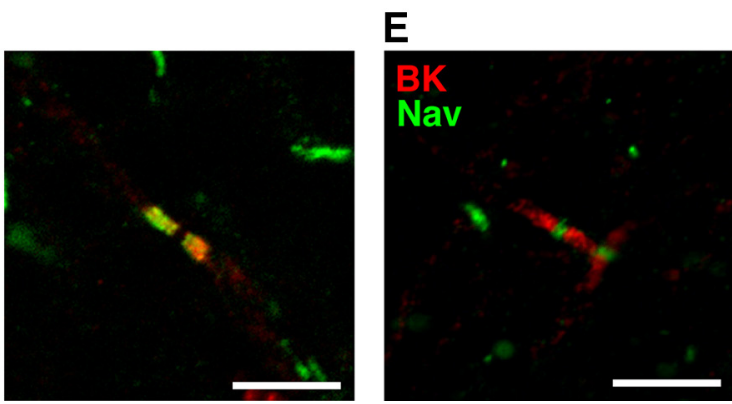

Figure 1. Paranodal localization of BK channels in the rat cerebellum. $A$, Non-uniform compact localization of BK channels in axons in the granule layer of the cerebellum. Rat cerebellar sections were immunolabeled with the L6/60 mouse mAb against BK (Slo1.1, red) and an antibody against an axonal marker, unphosphorylated neurofilament (Axon, green). Insets show magnified views of the immunolabeling. Scale bar, $50 \mu \mathrm{m}$. B , Two mAbs against BK recognize two distinct epitopes. Immunoblot of recombinant full-length BK channels and fragments representing residues 859-1169 and residues $664-865$, probed with L6/60 and L6/48 mAbs. C, The compact localization of BK channels in axons verified by immunolabeling with two distinct mAbs (L6/60, red; L6/48, green). Scale bar, $5 \mu \mathrm{m}$. D, Double immunolabeling with L6/60 (red) and an anti-Caspr antibody (green) showing their colocalization in the paranode. Scale bar, $5 \mu \mathrm{m}$. $\boldsymbol{E}$, Immunolabeling for Nav1. 6 (green) is present in the gap between the paired paranodal BK channel immunolabeling (red). Scale bar, $5 \mu \mathrm{m}$.

nals in brain neurons and less prominently in somata and dendrites (Vacher et al., 2008; Trimmer, 2015). We and others have shown that, in cerebellar Purkinje cells, BK channels are highly expressed in the dendrites and soma (Misonou et al., 2006; Sausbier et al., 2006). Studies using BK blockers and Slo1 knockout mice have suggested that, in Purkinje cells, somatodendritic BK channels contribute to the afterhyperpolarization (AHP) in the soma (Sausbier et al., 2004) and regulation of $\mathrm{Ca}^{2+}$ spikes in dendrites in Purkinje cells (Faber and Sah, 2003; Swensen and Bean, 2003; Womack and Khodakhah, 2004).

Here, we show that BK channels are also present in the myelinated axons of cerebellar Purkinje cells. Specifically, we show that BK channels colocalize at paranodes with Caspr, an axonal cell-adhesion molecule required for the paranodal axoglial junction (Einheber et al., 1997; Menegoz et al., 1997; Bhat et al., 2001). The paranode differs from the juxtaparanode in that small molecules and ions may be more accessible to the paranode (Mierzwa et al., 2010), such that paranodal ion channels would be fully functional under normal physiological conditions. Based on these findings, we tested whether paranodal BK channels regulate APs in Purkinje cell axons. Our results suggest that paranodal BK channels have a significant role in the myelinated axons of Purkinje cells to support reliable high-frequency conduction of APs.

\section{Materials and Methods}

Antibodies against BK channels. The production and validation of monoclonal antibodies (mAbs) against Slo1/KCa1.1/BK have been described previously (Misonou et al., 2006). Briefly, L6/48 and L6/60 mAbs against the mouse Slo1 (mSlo) channel subunit were raised against a GST-mSlo1 fusion protein corresponding to amino acids 690-1196 of mSlo1 (GenBank accession number AAA39746). Within this fragment, L6/48 binds within amino acids 859-1169, and L6/60 binds within amino acids $690-$ 715 (Fig. 1). Conditioned media from hybridoma clones were screened by chemiluminescence ELISA against COS-1 cells expressing full-length human Slo1 (Meera et al., 1997) and then further selected based on immunofluorescence labeling of COS-1 cells transfected with the same human Slo1 cDNA. Both mAbs were validated against BK channel knock-out mice (Misonou et al., 2006). The L6 mAbs can be obtained from the University of California, Davis/National Institutes of Health NeuroMab Facility (Davis, CA).

Immunolabeling. All animal use procedures were in strict accordance with the Guide for the Care and Use of Laboratory Animals described by the National Institutes of Health and approved by institutional animal 
use committees. Sprague Dawley rats, wild-type C57BL/6 mice, and Caspr-deficient mice (Gollan et al., 2003) were used. Animals were anesthetized with $60 \mathrm{mg} / \mathrm{kg}$ pentobarbital (intraperitoneal) and perfused briefly with a saline solution, followed by $4 \%$ paraformaldehyde in $0.1 \mathrm{M}$ phosphate buffer, $\mathrm{pH}$ 7.4. Sagittal brain sections (40 $\mu \mathrm{m}$ thick) were prepared as described previously (Rhodes et al., 1997; Hermanstyne et al., 2010). Brain sections were permeabilized with $0.1 \%$ Triton X-100 in Tris-buffered saline ( $10 \mathrm{~mm}$ Tris, $\mathrm{pH} 7.5$, and $0.15 \mathrm{M} \mathrm{NaCl}$ ). Sections were blocked with $10 \%$ goat serum and then incubated overnight at $4^{\circ} \mathrm{C}$ with $\mathrm{L} 6 / 60 \mathrm{mAb}$ (IgG2a) or L6/48 mAb (IgG1) (each at $10 \mu \mathrm{g} / \mathrm{ml}$ ) and mouse mAbs raised against Kv1.2 (K14/16, IgG2b, $1 \mu \mathrm{g} / \mathrm{ml})$, Caspr (K65/35, IgG1, $1 \mu \mathrm{g} / \mathrm{ml}$ ), and Nav1.6 (K87A/10, IgG1, $5 \mu \mathrm{g} / \mathrm{ml}$; all from the University of California, Davis/National Institutes of Health NeuroMab Facility), a mouse mAb cocktail neurofilament $\mathrm{H}$ (BioLegend), rabbit polyclonal antibodies against $\beta$ IV spectrin (Yang et al., 2004), or rabbit polyclonal antibodies against parvalbumin (Merck Millipore). Sections were then incubated with species-specific or mouse IgG subclass-specific Alexa Fluor-conjugated secondary antibodies (Invitrogen). Fluorescent images were taken with a 24-bit CCD camera installed on a Carl Zeiss Axiovert 200M microscope with a $63 \times, 1.3$ numerical aperture (NA) lens and Apotome, using Axiovision software. Most of the images are maximum projection images from multiple optical sections.

Preparation of brain membrane fraction. Crude brain membrane fractions and detergent-resistant fractions were prepared from rats and mice as described previously (Schafer et al., 2004; Ogawa et al., 2006). Either whole brains or isolated cerebella were homogenized in ice-cold homogenization buffer containing $0.32 \mathrm{M}$ sucrose, $5 \mathrm{~mm}$ sodium phosphate, $\mathrm{pH}$ 7.4, and $1 \mathrm{~mm}$ sodium fluoride, containing $1 \mathrm{~mm}$ phenylmethylsulfonyl fluoride (PMSF), $2 \mu \mathrm{g} / \mathrm{ml}$ aprotinin, $1 \mu \mathrm{g} / \mathrm{ml}$ leupeptin, $2 \mu \mathrm{g} / \mathrm{ml}$ antipain, and $10 \mu \mathrm{g} / \mathrm{ml}$ benzamidine ( $10 \mathrm{ml} / \mathrm{g}$ wet tissue weight). Crude homogenates were then centrifuged at $600 \times g$ for $10 \mathrm{~min}$ to remove debris and nuclei. The resulting supernatant was centrifuged at $45,000 \times$ $g$ for $60 \mathrm{~min}$. This pellet was then resuspended in $2.5 \mathrm{ml}$ of ice-cold homogenization buffer per gram of brain used. Protein concentrations were determined using the BCA method (Pierce).

Detergent-insoluble membrane fractions were isolated by solubilizing brain membrane fractions in 1\% Triton X-100 lysis buffer $(20 \mathrm{~mm}$ Tris$\mathrm{HCl}, \mathrm{pH}$ 8.0, 10 mм EDTA, $0.15 \mathrm{~m} \mathrm{NaCl}, 10 \mathrm{~mm}$ iodoacetamide, $0.5 \mathrm{~mm}$ PMSF, $10 \mathrm{~mm}$ sodium azide, and the same mixture of protease inhibitors as described above) at a concentration of $1 \mathrm{mg} / \mathrm{ml}$ protein for $1 \mathrm{~h}$ on a rotator at $4^{\circ} \mathrm{C}$. The resulting lysate was centrifuged at $13,000 \times g$ for 30 $\min$ to separate the detergent-soluble and -insoluble fractions. Detergent-insoluble fractions were resuspended to $1 \mathrm{ml}$ in lysis buffer (without Triton X-100). The pellet suspension was then mixed with $1 \mathrm{ml}$ of $2 \mathrm{M}$ sucrose. The resulting mixture was then overlaid with $2 \mathrm{ml}$ of $1 \mathrm{M}$ sucrose and $1.5 \mathrm{ml}$ of $0.2 \mathrm{M}$ sucrose. Samples were then centrifuged for $19 \mathrm{~h}$ at $192,000 \times \mathrm{g}$, and $0.4 \mathrm{ml}$ fractions were then collected from the top of the tube. Sucrose and protein concentrations were measured for each fraction. Proteins were concentrated by overnight ethanol precipitation. The pellets were then resuspended in $100 \mu \mathrm{l}$ of reducing sample buffer, boiled, and analyzed by SDS-PAGE and immunoblotting.

Immunoblotting. Proteins were separated on $7.5 \%$ SDS polyacrylamide gels (SDS-PAGE), transferred to nitrocellulose membrane, and immunoblotted with L6/48 or L6/60, as described previously (Misonou et al., 2005). The blots were incubated with HRP-conjugated secondary antibodies (ICN Biomedicals), followed by enhanced chemiluminescence reagent (PerkinElmer Life and Analytical Sciences). Immunoreactive bands were visualized by exposing the blot to $\mathrm{x}$-ray film.

Slice preparation. Cerebellar slices were prepared from C57BL/6 mice at postnatal day 25 (P25) to P35 of either sex as described previously (Hirono et al., 2012). The mice were treated with $\mathrm{CO}_{2}$ and decapitated, and their cerebella were removed rapidly. Parasagittal slices $(250 \mu \mathrm{m}$ thick) of the cerebellar vermis were cut with a vibrating microtome (VT1200S; Leica) in an ice-cold extracellular solution containing $252 \mathrm{~mm}$ sucrose, $3.35 \mathrm{~mm} \mathrm{KCl}, 21 \mathrm{~mm} \mathrm{NaHCO}, 0.6 \mathrm{~mm} \mathrm{NaH}_{2} \mathrm{PO}_{4}, 9.9 \mathrm{~mm}$ glucose, $0.5 \mathrm{mM} \mathrm{CaCl}_{2}$, and $10 \mathrm{mM} \mathrm{MgCl}_{2}$ and gassed with a mixture of $95 \%$ $\mathrm{O}_{2}$ and $5 \% \mathrm{CO}_{2}, \mathrm{pH}$ 7.4. The slices were maintained at room temperature for at least $1 \mathrm{~h}$ in a holding chamber, in which they were submerged in artificial CSF (ACSF) containing the following (in mM): $138.6 \mathrm{NaCl}, 3.35$
$\mathrm{KCl}, 21 \mathrm{NaHCO}_{3}, 0.6 \mathrm{NaH}_{2} \mathrm{PO}_{4}, 9.9$ glucose, $2 \mathrm{CaCl}_{2}$, and $1 \mathrm{MgCl}_{2}$ (bubbled with $95 \% \mathrm{O}_{2}$ and $5 \% \mathrm{CO}_{2}$ to maintain the $\mathrm{pH}$ at 7.4).

Electrophysiology. Individual slices were transferred to a recording chamber attached to the stage of a microscope (BX51WI; Olympus) and superfused with oxygenated ACSF. Purkinje cells were identified visually under Nomarski optics with a water-immersion objective $(60 \times, 0.90$ NA). After establishing the whole-cell patch clamp, the membrane potential was held at approximately $-65 \mathrm{mV}$ under a current-clamp mode with a patch pipette (2-3 $\mathrm{M} \Omega$ ) filled with the potassium methanesulfonate-based internal solution containing the following (in mM): $120 \mathrm{KCH}_{3} \mathrm{SO}_{3}, 25 \mathrm{KCl}, 0.1 \mathrm{CaCl}_{2} 1.0 \mathrm{~K}$-EGTA, $10.0 \mathrm{Na}$-HEPES, 3.0 Mg-ATP, and 0.4 Na-GTP, pH 7.4. To visualize the axon, Alexa Fluor 594 $(40 \mu \mathrm{M})$ was added to the internal solution. Neurons with no or very short axons were not used. To block synaptic transmissions, $10 \mu \mathrm{M}$ NBQX, $30 \mu \mathrm{M}$ APV, $10 \mu \mathrm{M}$ SR95531 [2-(3-carboxypropyl)-3-amino-6(4-methoxyphenyl)pyridazinium bromide], and $2 \mu \mathrm{M}$ strychnine were added to the ACSF throughout the recordings. To evoke antidromic APs in Purkinje cells, a bipolar tungsten stimulating electrode was placed in the white matter, and focal stimulation $(30-60 \mathrm{~V}, 0.1-0.2 \mathrm{~ms})$ was applied to the axon at $0.067-0.1 \mathrm{~Hz}$. For recording of synaptic currents, deep cerebellar nucleus (DCN) neurons were voltage clamped at -20 to $0 \mathrm{mV}$. Recordings were made from large neurons with somatic diameter of $\sim 20 \mu \mathrm{m}$, most of which are thought to correspond to the glutamatergic projection neurons in the DCN (Telgkamp and Raman, 2002; Uusisaari et al., 2007). A patch pipette was filled with the cesium methanesulfonate-based internal solution containing the following (in mM): $140 \mathrm{CsCH}_{3} \mathrm{SO}_{3}, 5 \mathrm{CsCl}, 0.1 \mathrm{CaCl}_{2}, 1.0 \mathrm{~K}$-EGTA, $10.0 \mathrm{Na}$-HEPES, 0.6 QX-314, 3.0 Mg-ATP, and 0.4 Na-GTP, pH 7.4. IPSCs were evoked by focal stimulation $(30-60 \mathrm{~V}, 0.04-0.12 \mathrm{~ms})$ through a bipolar tungsten stimulating electrode or a concentric bipolar electrode (FHC) placed in the white matter. Glutamate transmission was blocked by kynurenic acid ( $1 \mathrm{~mm}$ ) or $10 \mu \mathrm{M}$ NBQX and $30 \mu \mathrm{M}$ APV added to the ACSF. Alexa Fluor $594(40 \mu \mathrm{M})$ was also added to the patch pipette solution to examine morphology of recorded cells. Series resistance (10-18 M $\Omega$ ) was compensated by $60-70 \%$ and monitored with $2 \mathrm{mV}$ hyperpolarizing voltage pulse $(30-50 \mathrm{~ms})$ every $15 \mathrm{~s}$, and experiments were discarded if the value changed $>20 \%$. Signals were recorded with a MultiClamp 700B amplifier (Molecular Devices) and pClamp 10.3 software (Molecular Devices), digitized, and stored on a computer disk for offline analysis. All signals were filtered at $4 \mathrm{kHz}$ and sampled at $10-20 \mathrm{kHz}$. All experiments were performed at room temperature $\left(23-26^{\circ} \mathrm{C}\right)$.

Drug application for electrophysiology. Drugs were applied to the axon in pressure pulses (3-6 psi, $400 \mathrm{~ms}$ duration) at $0.5 \mathrm{~Hz}$ using a micropressure ejection system (PV820 Pneumatic PicoPump; World Precision Instruments) with a glass pipette (5-10 $\mu \mathrm{m}$ tip diameters). Iberiotoxin, NBQX, paxilline, penitrem A, and SR95531 were obtained from Tocris Bioscience. Alexa Fluor 594 was obtained from Invitrogen. Tetrodotoxin (TTX) was obtained from Wako. All other chemicals were from Sigma.

Statistical analyses. Data are presented as the mean \pm SEM, unless noted otherwise. In electrophysiology experiments, the number of sample $(n)$ indicates the number of cells used for recording. However, slices from at least three different animals were used in each experiment. A $t$ value of $p<0.05$ was considered to be statistically significant. For multiple comparisons, two-way ANOVA was performed with post hoc multiple comparisons. All statistical analyses were performed using GraphPad Prism (GraphPad Software).

\section{Results}

\section{Axonal expression of Slo1/BK channels in the cerebellum}

The BK channel is highly expressed in Purkinje cells of the cerebellum, in which the majority of BK immunoreactivity is found in the soma and dendrites (Misonou et al., 2006). Here, using the specific mouse mAb L6/60 (Misonou et al., 2006), we found that Purkinje cells also express BK channels in their axons. Nonuniform BK labeling is present in a subset of axons running in the granule cell layer of the rat cerebellum (Fig. 1A). The inset images (Fig. $1 A$, insets) show that $\mathrm{BK}$ channels are concentrated into two small bands, with a clear gap between adjacent bands. The axonal 
A
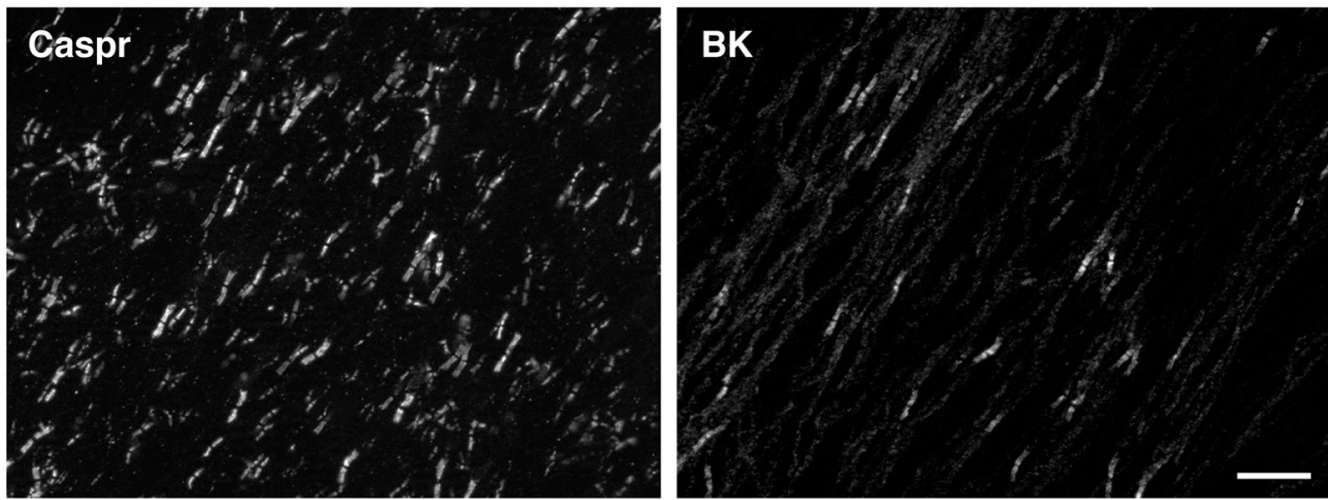

B

C
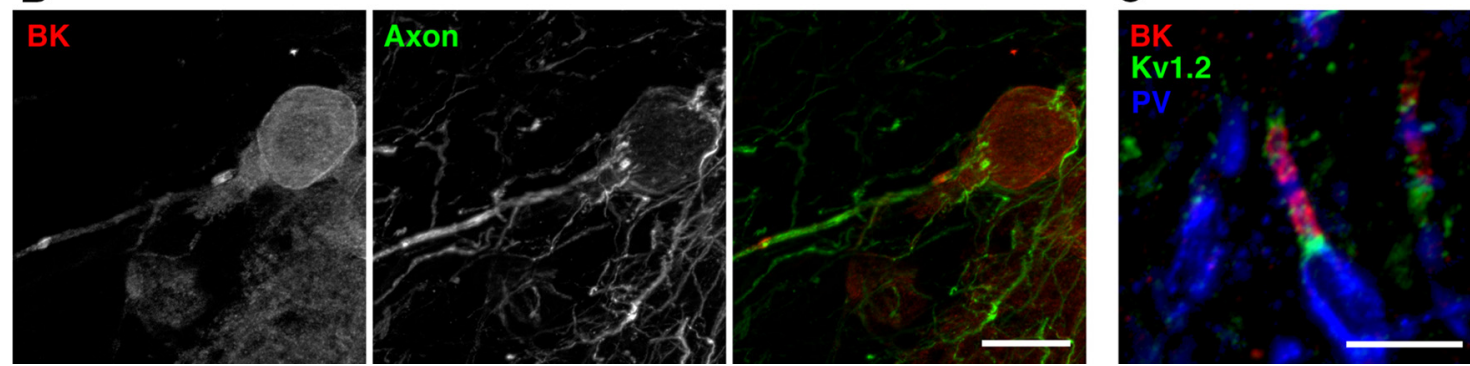

Figure 2. Paranodal BK channels in rat Purkinje cells. $A$, Paranodal BK channel immunolabeling was detected only in a subset of Caspr-positive paranodes in the cerebellar white matter. Scale bar, $20 \mu \mathrm{m}$. B, Paranodal BK channels (red) were detected near the Purkinje cell soma. The axon is labeled using an antibody against unphosphorylated neurofilament $\mathrm{H}$ (green). Scale bar, $20 \mu \mathrm{m}$. $\boldsymbol{C}$, Paranodal BK channel immunolabeling (red) found on parvalbumin (PV; blue)-positive axons in the white matter. Juxtaparanodes are immunolabeled using antibodies against Kv1.2 (green). Scale bar, $10 \mu \mathrm{m}$.

expression of BK channels was confirmed with another anti-BK channel $\mathrm{mAb}(\mathrm{L} 6 / 48)$ that binds to a region of the $\mathrm{BK}$ channel distinct from the L6/60 mAb (Fig. 1B,C). The clear gap between the opposed segments of BK channel immunoreactivity suggested they are expressed in the paranodal region of myelinated axons. Indeed, these BK-positive structures colabeled with antibodies recognizing the axonal paranodal cell-adhesion molecule Caspr (Fig. 1D). Furthermore, Nav1.6, the predominant nodal Nav channel in adult rodents, was found in the nodal gap between BKlabeled paranodes (Fig. 1E).

In addition to these axons in the granule cell layer, we also detected the paranodal $\mathrm{BK}$ channel expression in the white matter of the cerebellum (Fig. 2A). However, BK channels were detected in fewer than 10\% of Caspr-positive paranodes (Fig. 2A), a number consistent with the proportion of Purkinje cell axons in cerebellar white matter, in which mossy fiber and climbing fiber axons predominate (Palkovits et al., 1972). Moreover, prominent paranodal BK labeling was observed near the site of origin of Purkinje cell axons in the Purkinje layer (Fig. 2B). These considerations led us to suspect that BK channels are expressed specifically in the paranodes of Purkinje cell axons. To test this possibility, we triple immunolabeled cerebellar sections with anti-BK channel mAb L6/60, an antibody against the Purkinje cell marker parvalbumin, and an anti-Kv1.2 channel antibody that labels the juxtaparanodal domains of myelinated axons. As shown in Figure $2 C$, BK channels were restricted to the paranodes of parvalbumin-positive axons, indicating the specific expression of BK channels in Purkinje cell axons. Furthermore, paranodal BK channels were not detected in myelinated axons in other areas of the nervous system, including white matter tracts within the brain, optic nerve, and sciatic nerve. These results suggest that BK channels are found specifically in the paranodes of Purkinje cell axons.
Caspr-dependent localization of BK channels in the paranode Paranodal proteins have biochemical properties similar to raft proteins (Schafer et al., 2004). To determine whether BK channels in the cerebellum also have this property, we prepared detergent-soluble and -insoluble fractions (Ogawa et al., 2006) from the whole brain and the cerebellum of rat. As expected, Caspr was recovered mainly in the detergent-insoluble fraction from both whole-brain and cerebellar samples (Fig. 3A). This was also observed for the glial paranodal protein Neurofascin-155 (Schafer et al., 2004) but not for axonal Neurofascin-186, which localizes at the node (Davis et al., 1996; Fig. 3A). Furthermore, BK channel and Caspr proteins from the cerebellum were found in the low-density detergent-insoluble fractions isolated from sucrose gradients (Fig. $3 B$ ). Thus, a subset of BK channels in the cerebellum share similar biochemical characteristics with those of other paranodal membrane proteins (Schafer et al., 2004; Ogawa et al., 2006). Similar to other paranodal proteins (e.g., glycosylphosphatidylinositol-anchored contactin), a fraction of the BK channels remained detergent insoluble in Caspr-deficient mice (Gollan et al., 2003; Fig. 3C), indicating that some BK channels remain in raft-like structures independent of paranodal junctions. Consistent with this idea, BK channels are modified with palmitate (Jeffries et al., 2010), which is a posttranslational lipid modification that promotes the partitioning of proteins into detergent-insoluble lipid rafts (Levental et al., 2010).

To more directly examine the role of paranodal junctions in regulating BK channel localization, we also performed immunolabeling to examine BK channel localization in the cerebellum of Caspr-deficient mice. First, we confirmed the paranodal localization of BK channels in the cerebellum of wild-type mice (Fig. $3 D, E)$, indicating that the paranodal expression of $\mathrm{BK}$ channels is a common property of rodent Purkinje cells. In contrast, Caspr- 
A

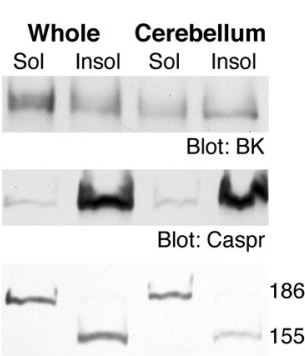

D

Blot: Neurofascin
B

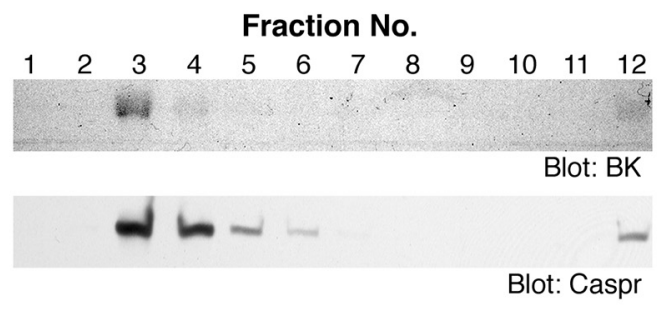

C

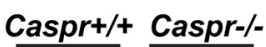

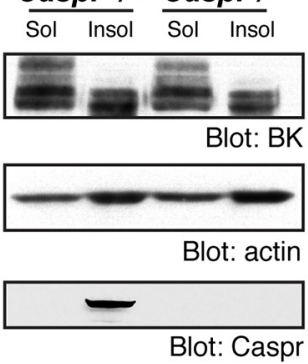
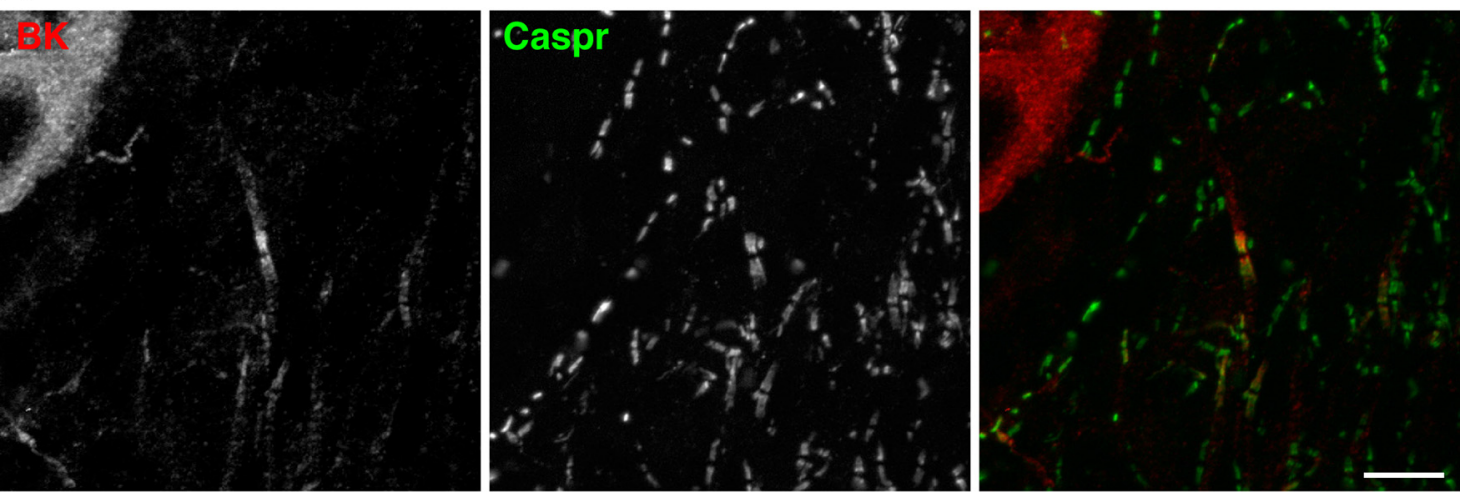

E

Caspr +/+

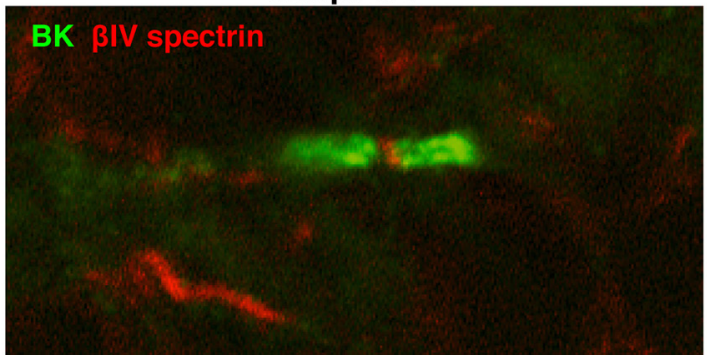

Caspr -/-

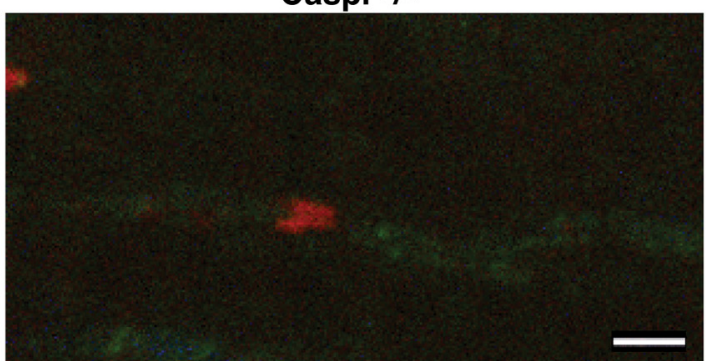

Figure 3. Paranodal localization of BK channels depends on an intact paranodal junction. $A$, Biochemical characteristics of $B K$ channels in the cerebellum. Membrane fractions were prepared from rat whole brain (Whole) or cerebellum. Membrane preparations were incubated with 1\% Triton X-100 for 30 min and separated into soluble (Sol) and insoluble (Insol) fractions by centrifugation. The samples were subjected to immunoblotting and probed for BK channels, the paranodal membrane protein Caspr, and another paranodal protein, Neurofascin. Note that only the paranodal 155 $\mathrm{kDa}$ isoform of Neurofascin was detected in the insoluble fraction. $\boldsymbol{B}$, Cofractionation of BK channels and Caspr. Detergent-insoluble fractions from the cerebellum were fractionated using sucrose-density gradient centrifugation. Both BK channels and Caspr were detected in the low-density paranodal protein-lipid complex fraction. $C$, Detergent insolubility of BK channels in the cerebella of wild-type (Caspr +/+) and Caspr-deficient (Caspr-/-) mice. Actin was used as a loading control. D, Paranodal BK channels in the mouse cerebellum. Mouse cerebellar sections were immunolabeled for BK channels (red) and Caspr (green). Scale bar, $10 \mu \mathrm{m}$. E, BK channels are not detected at paranodes in Caspr-deficient mice with disrupted paranodes. Cerebellar sections from wild-type (Caspr $+/+$ ) and Caspr-deficient (Caspr-/-) mice were immunolabeled for BK channels (green) and $\beta I V$-spectrin (red). Scale bar, $2 \mu \mathrm{m}$.

deficient mice completely lacked BK channels at the paranodes (Fig. 3E). Furthermore, despite the strong enrichment of BK channels at the adult paranodal junction, BK channel enrichment at paranodes lagged behind paranodal junction assembly during development in mice. For example, although Caspr immunoreactivity already defines paranodes at P19, paranodal BK labeling was not apparent until P23 and fully matured between P25 and P30 (Fig. 4A). Together, these results suggest that the paranodal clustering of BK channels is developmentally regulated by a Caspr- and paranodal junction-dependent mechanism.

\section{Axonal physiology of Purkinje cells in young adult} mouse slices

To determine whether paranodal BK channels regulate APs in myelinated axons, we measured APs evoked in the axon before and after local blockade of paranodal BK channels. Although axonal patch recordings have been performed on Purkinje cell axons of juvenile rats and mice (Clark et al., 2005; Khaliq and
Raman, 2005; Monsivais et al., 2005; Yang and Wang, 2013), myelination of the Purkinje cell axons prevented similar measurements in cerebellar slices from young adult mice older than P25, when paranodal BK expression becomes prominent (Fig. $4 A$ ). Therefore, we took an alternative approach. We evoked APs in the axon and recorded the resultant antidromic APs in the soma. By applying BK channel blockers to the axon and examining their effects on antidromic APs, we tested whether paranodal BK channels have significant roles in AP generation and conduction in the myelinated axons of Purkinje cells.

Purkinje cell somata were subjected to whole-cell patchclamp recording and infused with a fluorescent dye through the patch pipette to label the axons. After finding a cell with a long intact axon, a bipolar electrode was placed near the axon for extracellular stimulation. The position of the electrode was adjusted for maximum and stable responses. APs were evoked in distal axons with the extracellular electrode and recorded under the whole-cell patch-clamp mode at the soma of Purkinje cells 
A

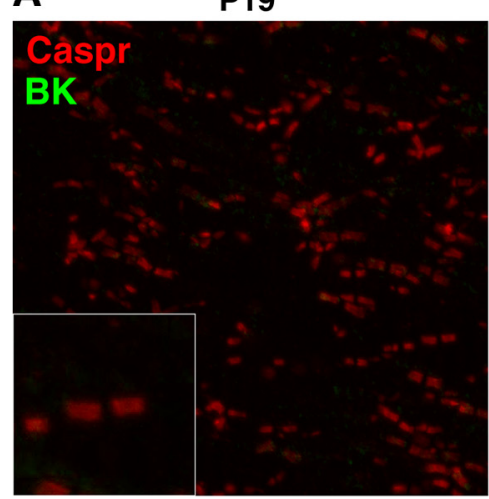

P23

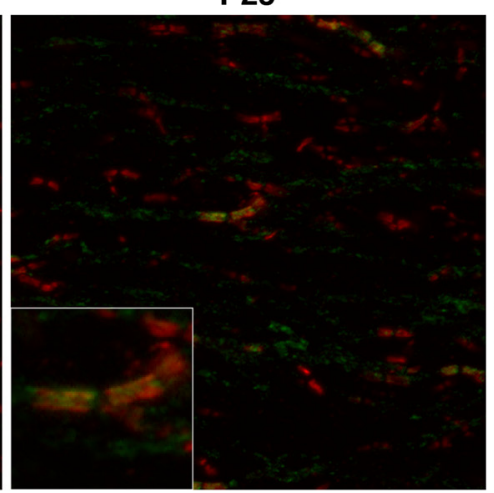

P30

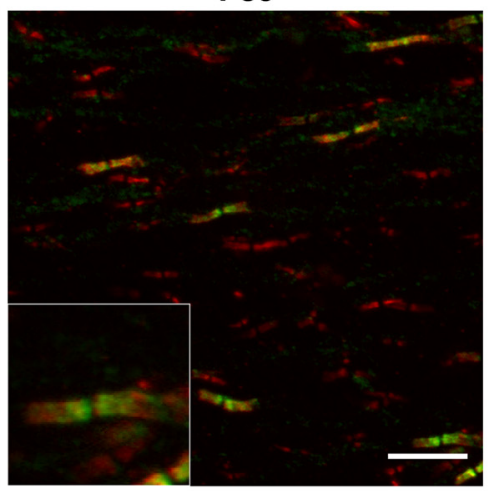

B

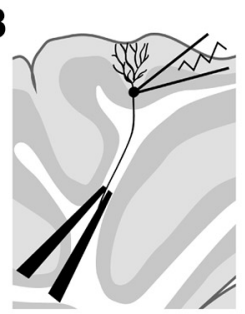

C

Distance from the soma

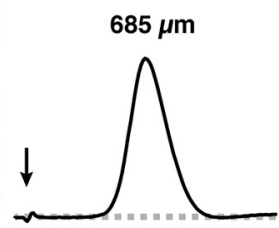

$480 \mu \mathrm{m}$

$0 \mu \mathrm{m}$
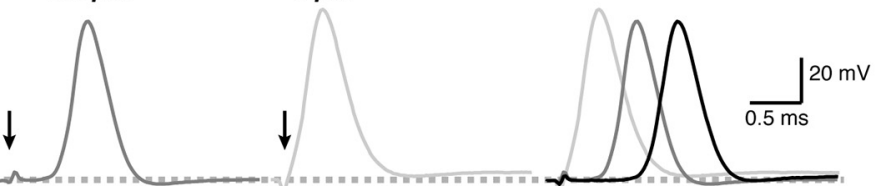

D

$100 \mathrm{~Hz}$

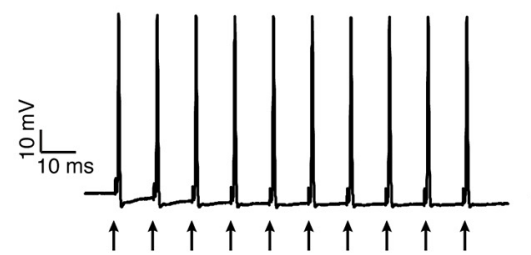

$200 \mathrm{~Hz}$
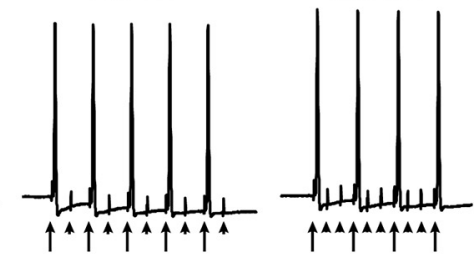

F

$100 \mathrm{~Hz}$

$200 \mathrm{~Hz}$

$300 \mathrm{~Hz}$
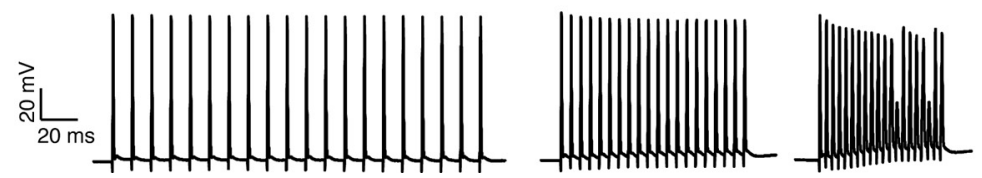

E

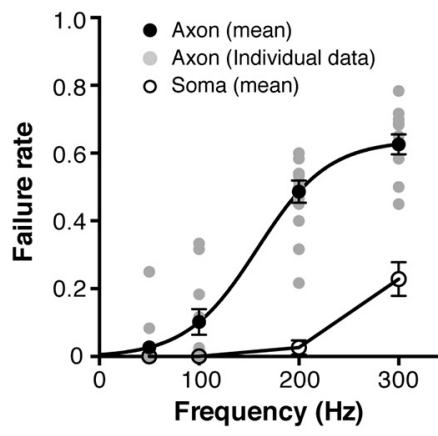

Figure 4. Recording of antidromic APs as an experimental model to investigate the role of paranodal BK channels. $A$, Immunolabeling of developing mouse cerebella from P19 to P30 with the $L 6 / 60$ (green) and anti-Caspr antibody (red). Paranodal BK channel immunolabeling was absent in P19 but becomes apparent at P23. Scale bar, $10 \mu \mathrm{m}$. Insets show magnified views of the paranodes. $\boldsymbol{B}$, Experimental setup to evoke and record antidromic APs. C, Antidromic APs evoked by stimulating the white matter at different distances from the soma. The arrows indicate the stimulation artifact. The distance-dependent delay indicates the antidromic nature of the signals. $\boldsymbol{D}$, Antidromic APs evoked at different stimulation frequencies. The arrows indicate the stimulation, and the arrowheads show failures. $E$, The failure rate of $A P s$ at different frequencies. APs were evoked in either the axon or the soma. Error bars indicate SEM $(n=50)$. Data from the axonal stimulation were fitted with a Boltzmann sigmoidal curve. $F$, Reliable firing of APs at the soma. Extracellular stimulation was given to the soma to evoke APs at the soma.

(Fig. 4B), while keeping the somatic resting membrane potential at approximately $-65 \mathrm{mV}$. To verify that the recorded APs originated in the distal axon, we placed the stimulation electrode at different distances from the soma to confirm a distancedependent delay in the onset of APs. When the stimulation was given at $685 \mu \mathrm{m}$ from the soma, there was a significant delay between the stimulation and the onset of the AP recorded at the soma (Fig. 4C). This delay was shortened, as the stimulation electrode was moved closer to the soma. The average conduction velocity computed from the latency was $0.52 \pm 0.05 \mathrm{~m} / \mathrm{s}(n=21)$, a value consistent with that reported previously (Clark et al., 2005).

Given that we could evoke and record antidromic APs from Purkinje cells, we next investigated the properties of antidromic APs in Purkinje cell axons, particularly their fidelity during highfrequency firing. Cerebellar Purkinje cells typically fire at frequencies above $50 \mathrm{~Hz}$, such that we stimulated Purkinje cell axons at 50,100, 200, and $300 \mathrm{~Hz}$. Surprisingly, we observed substantial failures of APs at stimulation frequencies above 100 $\mathrm{Hz}$ (Fig. 4D,E). This was not attributable to reduced excitability of the soma in our preparation, because APs were evoked without failures even at $200 \mathrm{~Hz}$ when the extracellular stimulation was applied to the soma (Fig. $4 E, F$ ); we do not know whether this difference reflects a failure of stimulation or the nature of distal axons (see Discussion). Nevertheless, our data show that the maximum net frequency of antidromic AP firing was $\sim 120 \mathrm{~Hz}$.

\section{Paranodal BK channels modulate high-frequency firing in} Purkinje cell axons

To investigate directly the physiological role of paranodal BK channels, we examined the effects of BK channel blockers on antidromic APs. Because BK channels are also expressed in the soma and dendrites of Purkinje cells, we pursued locally inhibiting only axonal BK channels through focal application of BK channel blockers. To demonstrate the precision and specificity of 
A
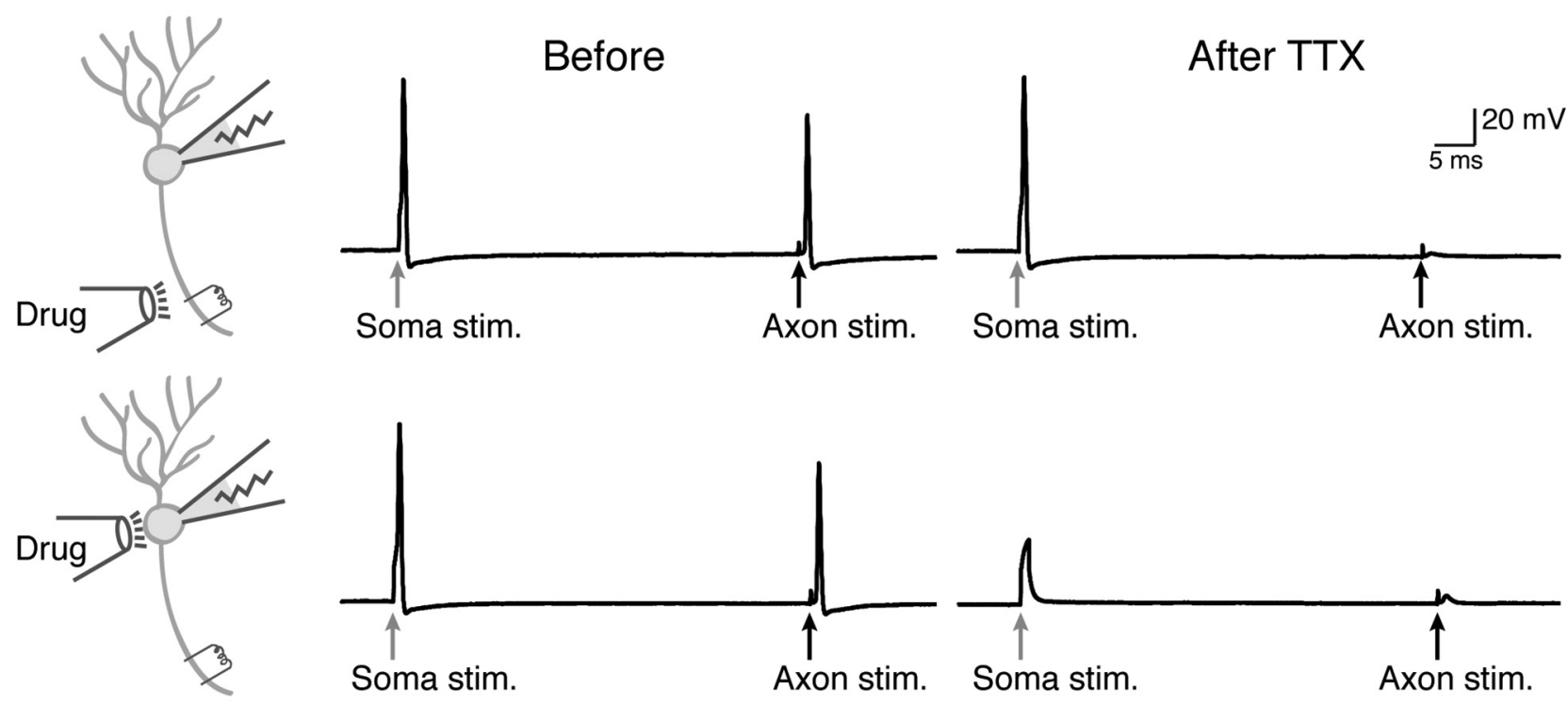

B

Control

Penitrem A

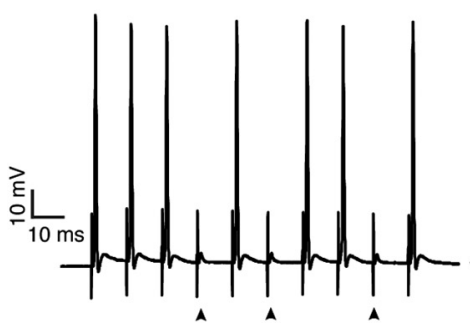

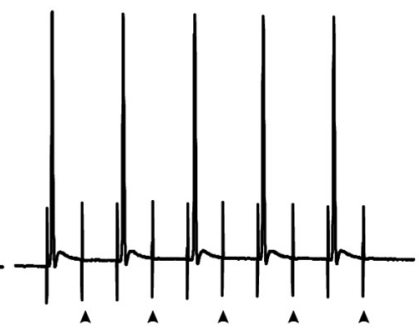

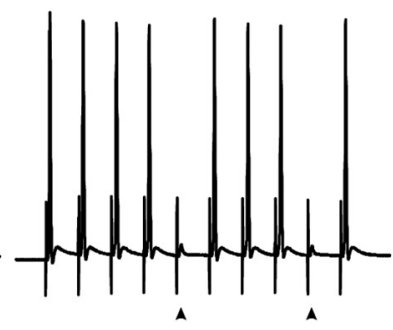

Washout

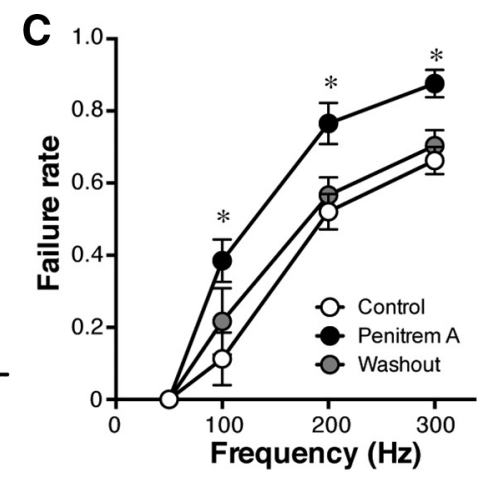

Figure 5. Increased failure of antidromic APs by BK channel inhibition. A, Verification of the specificity of local drug application. TTX was applied focally to either the axon or the soma as indicated in the schematic diagram. Before TTX application, both somatic current injection and extracellular axonal stimulation evoked APs. After applying TTX at $0.5 \mu$ m for 5 min to the axon, only the antidromic AP evoked by the axonal stimulation was attenuated, whereas the somatic application blocked both. Arrows show the timing of stimulation. $\boldsymbol{B}$, Increased failure of antidromic APs by penitrem $\mathrm{A}$ at $100 \mathrm{~Hz}$. The arrowheads indicate failures. Before the drug application, there were a few failures of antidromic APs observed at $100 \mathrm{~Hz}$ stimulation. Application of penitrem A at $10 \mu \mathrm{M}$ to the axon for 5 min substantially increased failures. This effect was reversed by a 10 min washout of the drug. C, Pooled data $(n=4)$. ${ }^{*} p=0.001$ (at $100 \mathrm{~Hz}$ ), 0.002 (at $200 \mathrm{~Hz}$ ), and 0.008 (at 300 $\mathrm{Hz}$ ), respectively, for Control versus Penitrem $\mathrm{A}$, and $p=0.015$ (at $200 \mathrm{~Hz}$ ) and 0.046 (at $300 \mathrm{~Hz}$ ) for Washout versus Penitrem A.

the local drug application, we first locally applied the $\mathrm{Na}^{+}$channel inhibitor TTX $(0.5 \mu \mathrm{M})$ in brief pulses to the axon using a glass pipette and then evoked APs in the soma and the axon. As shown in Figure $5 A$, both somatic and axonal stimulation evoked APs, but only the antidromic APs were inhibited after local axonal application of TTX. In contrast, somatic application of TTX blocked both APs (Fig. 5A).

We next focally applied BK channel blockers to the axon and examined their effects on antidromic APs. We found that the membrane-permeable BK channel blocker penitrem A $(10 \mu \mathrm{M}$; Knaus et al., 1994) significantly increased the failure rate of antidromic APs (from $0.11 \pm 0.07$ to $0.39 \pm 0.06$ at $100 \mathrm{~Hz}, p=$ $0.001, n=4$; Fig. $5 B, C)$. This effect was reversible, such that the failure rate decreased to the control level after washing out the drug for $10 \mathrm{~min}$. We also tested other BK channel blockers, including iberiotoxin (Galvez et al., 1990) and paxilline (Knaus et al., 1994). Interestingly, the membrane-impermeable iberiotoxin $(250 \mathrm{nM})$ did not show significant effects on failure rates (from $0.02 \pm 0.02$ to $0.00 \pm 0.00$ at $100 \mathrm{~Hz}, p=0.956, n=4)$ of antidromic APs (Fig. 6A). Consistent with the limited permeability of the paranodal junction (Mierzwa et al., 2010), we speculate that this may be attributable to the fact that paranodal BK chan- nels are covered with glial membranes and not readily accessible to the relatively large $(4.2 \mathrm{kDa})$ iberiotoxin. In contrast, membrane-permeable paxilline $(10 \mu \mathrm{M})$ elicited an effect similar to penitrem $A$, such that it increased the failure rate of antidromic APs (from $0.09 \pm 0.05$ to $0.25 \pm 0.13$ at $100 \mathrm{~Hz}, p=0.015, n=6$; Fig. $6 B$ ), particularly at 100 and $200 \mathrm{~Hz}$ stimulation (Fig. $6 C$ ). The increased failure was observed reliably in all cells examined (Fig. $6 D)$. As a result, the maximum net firing rate decreased from $120.8 \pm 14.1$ to $87.6 \pm 16.1 \mathrm{~Hz}(p=0.033, n=6$; Fig. $6 E)$.

Although we did not detect substantial levels of BK channels in the internodal region, it is possible that the effects of BK blockers result, at least in part, from blocking internodal BK channels expressed at levels sufficiently low to avoid detection in our immunolabeling experiments. To investigate this, we tested two predictions. First, the activation of internodal BK channels would cause shunting. Second, the activation of internodal BK channels would decrease the membrane resistance and the length constant. Therefore, inhibition of internodal BK channels would either decrease the failure rate of antidromic APs or increase the conduction velocity. Our results shown above demonstrated clearly that the former is not the case. We also did not observe any changes in the conduction velocity during axonal BK channel 
A

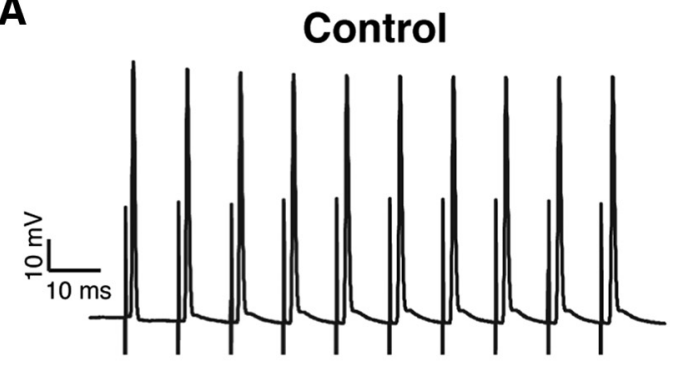

B<smiles>[B]=CO[Ga]</smiles>

Iberiotoxin

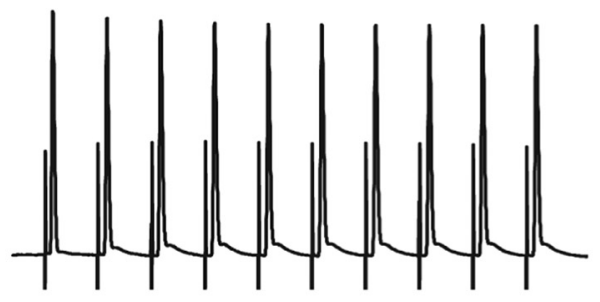

Paxilline

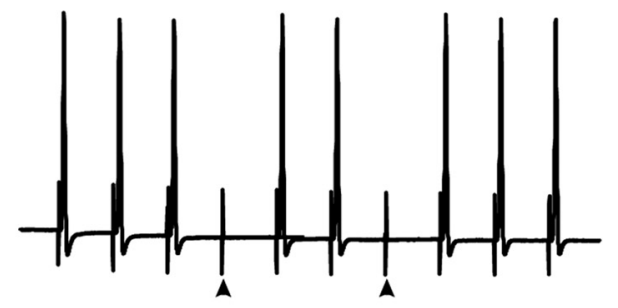

E

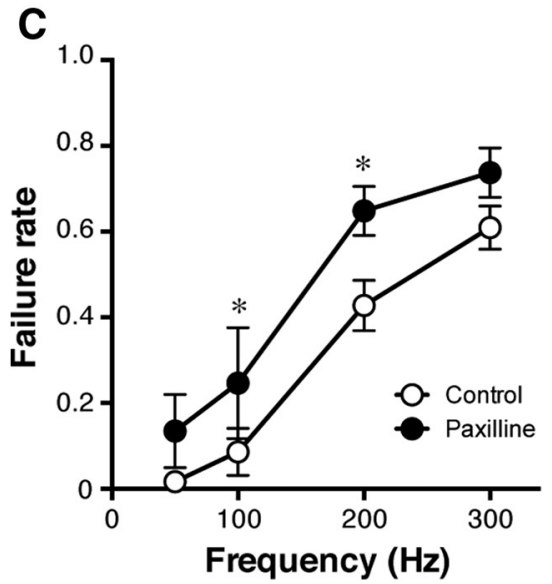

D

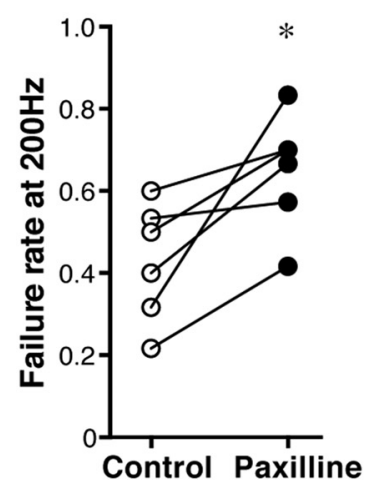

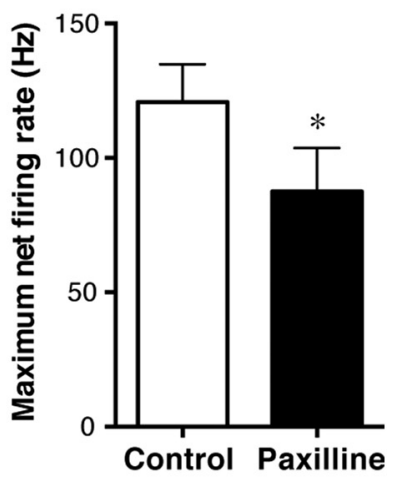

Figure 6. Increased failure of antidromic APs by membrane-permeable, but not membrane-impermeable, BK channel blockers. A, No significant effect of iberiotoxin (250 $\mathrm{nm}$ ) on the antidromic APs at $100 \mathrm{~Hz}$. B, Increased failure of antidromic APs by paxilline $(10 \mu \mathrm{m})$ at $100 \mathrm{~Hz}$. The arrowheads indicate failures. C, Pooled data for paxilline $(n=6) .{ }^{*} p=0.015($ at $200 \mathrm{~Hz})$ and 0.001 (at 300 $\mathrm{Hz}$ ). $\boldsymbol{D}$, The failure rate at $200 \mathrm{~Hz}$ stimulation before and after the paxilline application. $p=0.02$. $E$, Decrease of the maximum net firing rate after the paxilline treatment. ${ }^{*} p=0.03$.

inhibition $(100.0 \pm 9.8 \%$ in control vs $101.0 \pm 11.2 \%$ after paxilline treatment, $n=6$ ), indicating that the contribution of internodal BK channels is minuscule. Together, these results show that local (i.e., axonal) inhibition of BK channels reduces the fidelity of axonal AP conduction and suggest that paranodal BK channels support the high-frequency firing of Purkinje cell axons.

Potential involvement of voltage-gated $\mathrm{Ca}^{2+}$ channels in the nodal region

Because BK channels generally require an increase in $\left[\mathrm{Ca}^{2+}\right]_{\mathrm{i}}$ to be activated by depolarization within the physiological range of membrane potentials (Barrett et al., 1982), they are often tightly coupled with voltage-gated $\mathrm{Ca}^{2+}$ (Cav) channels (Grunnet and Kaufmann, 2004; Liu et al., 2004; Berkefeld et al., 2006), which provide $\mathrm{Ca}^{2+}$ for their activation. $\mathrm{Ca}^{2+}$ transients in unmyelinated axons have been reported in several types of neurons (LevRam and Ellisman, 1995; Tsantoulas et al., 2013; Sargoy et al., 2014), including immature Purkinje cells (Callewaert et al., 1996). Thus, Cav channels may be nearby in either the nodal or the paranodal membranes to participate in the activation of BK channels. To test this possibility, we first determined whether $\mathrm{Ca}^{2+}$ influx is necessary for reliable high-frequency firing of an- tidromic APs. Recording was performed before and after applying ACSF without $\mathrm{Ca}^{2+}$ for $5 \mathrm{~min}$. Importantly, the failure rate of antidromic APs at $100 \mathrm{~Hz}$ increased significantly after the treatment (from $0.11 \pm 0.11$ to $0.74 \pm 0.13, p=0.001$ at $100 \mathrm{~Hz}, n=$ 3; Fig. $7 A, B$ ). This effect was also reversible (Fig. 7A). These results indicate that $\mathrm{Ca}^{2+}$ influx influences AP firing in the axon. We next examined the effect of $\mathrm{Ni}^{2+}$, which is a relatively broad inhibitor of Cav channels (Tsien et al., 1988). We chose $\mathrm{Ni}^{2+}$ over other more specific Cav blockers because $\mathrm{Ni}^{2+}$-sensitive Cav channels have been reported in the axon of Purkinje cells (Bender and Trussell, 2009) and because Cav channels, like paranodal BK channels, might be covered by glial membranes and less accessible to those large organic inhibitors. Interestingly, $\mathrm{Ni}^{2+}(100 \mu \mathrm{M})$ showed an effect similar to paxilline and penitrem $\mathrm{A}$ and increased the failure of antidromic APs when applied locally to the axon from $0.51 \pm 0.03$ to $0.67 \pm 0.07$ at $200 \mathrm{~Hz}(p=0.030, n=$ 4; Fig. $7 C-E$ ). This also resulted in a significant reduction in the maximum net firing rate of antidromic APs from $125.0 \pm 15.0$ to $88.3 \pm 4.7 \mathrm{~Hz}(p=0.041, n=4$; Fig. $7 F)$. These results suggest that $\mathrm{Ni}^{2+}$-sensitive Cav channels support high-frequency firing of APs in the axon and may provide $\mathrm{Ca}^{2+}$ for the activation for paranodal BK channels. 
A

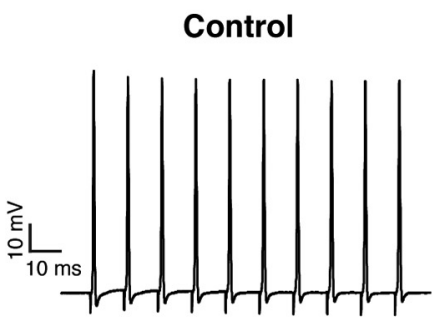

ACSF w/o $\mathrm{Ca}^{2+}$
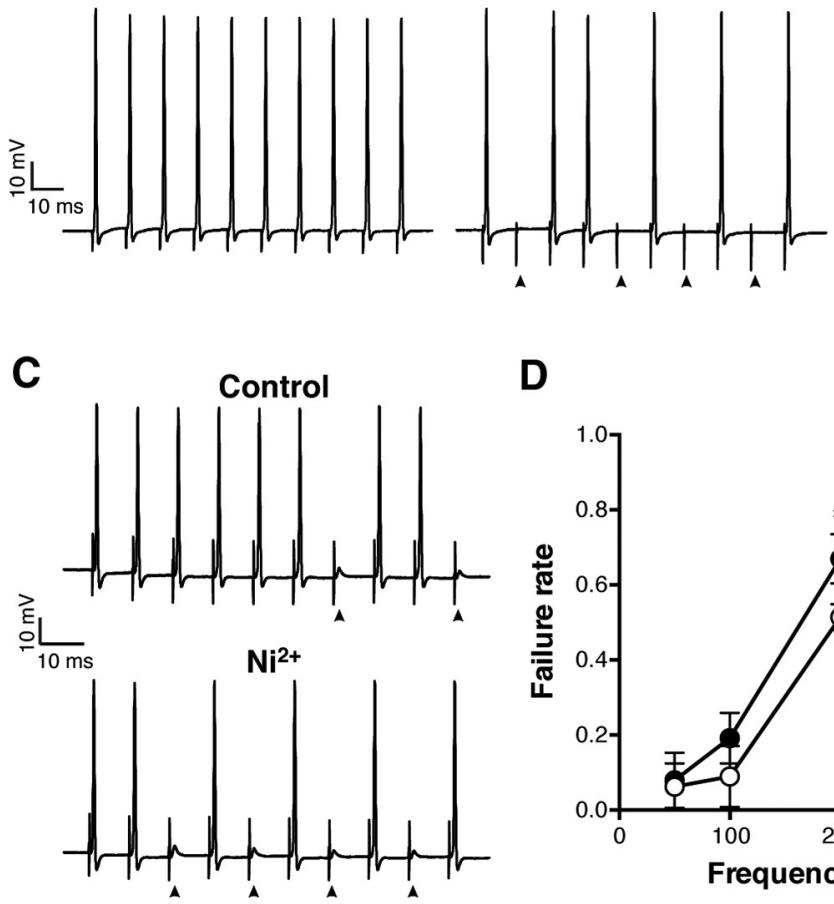

D

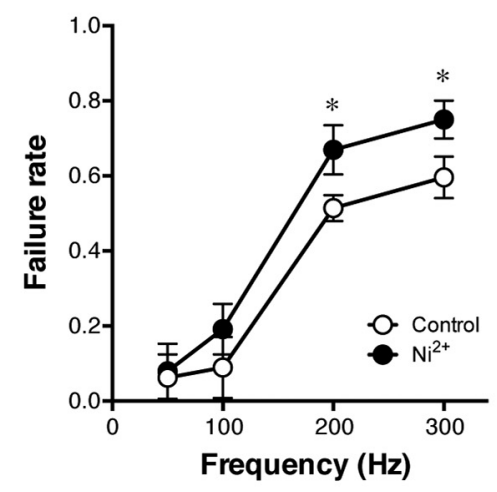

Normal ACSF

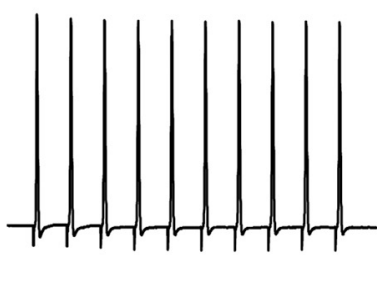

E

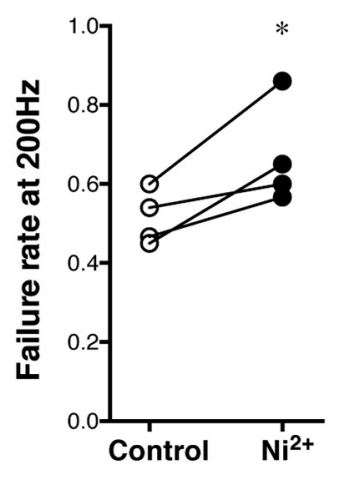

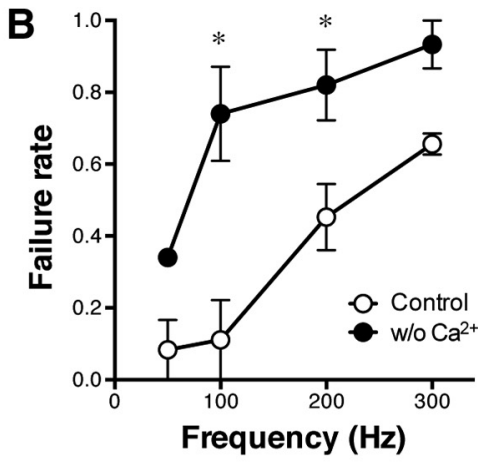

$F$

Figure 7. Increased failure of antidromic APs by inhibiting $\mathrm{Ca}^{2+}$ influx. $A$, The failure of antidromic APs was also increased by applying ACSF with no $\mathrm{Ca}^{2+}$ (ACSF w/0 Ca ${ }^{2+}$ ) to the axon. This effect was reversed in normal ACSF (Normal ACSF). $\boldsymbol{B}$, Pooled data $(n=3) .{ }^{*} p=0.001$ (at $100 \mathrm{~Hz}$ ) and 0.019 (at $200 \mathrm{~Hz}$ ). $\boldsymbol{C}$, Similar increase in the failure rate induced by Ni ${ }^{2+}$. Ni ${ }^{2+}$ at $100 \mu \mathrm{M}$ was applied to the axon for $5 \mathrm{~min}$. $\boldsymbol{D}$, Pooled data $(n=4) .{ }^{*} p=0.03$. $\boldsymbol{E}$, The failure rate at $200 \mathrm{~Hz}$ stimulation before and after the Ni ${ }^{2+}$ application. $p=0.04 . \boldsymbol{F}$, Decrease of the maximum net firing rate after the $\mathrm{Ni}^{2+}$ treatment. ${ }^{*} p=0.04$.

\section{Effect of the axonal BK channels on the output of the cerebellar cortex}

We have shown so far that axonal BK channels localized to the paranodal region regulate axonal APs, evidenced by the effects of BK channel blockers on antidromic APs. Purkinje cell axons diverge extensively in the white matter and form multiple synapses on neurons in the DCNs. This extensive branching is thought to make axonal APs intrinsically prone to failures (Bucher and Goaillard, 2011; Debanne et al., 2011). Therefore, the regulation of axonal APs by paranodal BK channels would affect the final synaptic output of Purkinje cells to DCNs. To test this, we also examined the effect of BK channel blockers on IPSCs in DCN neurons evoked by stimulating Purkinje cell axons in the white matter (Fig. 8A). The pipette solution contained cesium instead of potassium to block $\mathrm{K}^{+}$channels in the postsynaptic DCN neurons. Penitrem A was then applied locally to the cerebellar white matter away from the DCNs. We predicted that increased failures of APs in the axons by penitrem A would result in the overall reduction of IPSCs rather than occasional failures of IPSCs because these postsynaptic neurons receive inputs from multiple Purkinje cell axons (Fig. $8 B$ ). Based on the results from antidromic AP recordings, we chose to stimulate the axons at 100 $\mathrm{Hz}$, at which frequency we observed a significant and consistent increase of failures of antidromic APs by penitrem A (Fig. 5 B, C) and can reliably measure phasic IPSCs (Telgkamp et al., 2004). In fact, we found that the local puff application of penitrem $A$ to the axon significantly ( $p=0.045$, two-way ANOVA, $n=10$ ) decreased the amplitude of phasic IPSCs (Fig. $8 C$ ). Similar to the effect on antidromic APs, this decrease was reversed after $15 \mathrm{~min}$ washout of the drug (Fig. $8 \mathrm{C}$ ). The effect of axonal BK channel inhibition was the opposite of what was expected from the inhibition of presynaptic BK channels, which would increase the IPSC amplitude by extending $\mathrm{Ca}^{2+}$ influx. In contrast, the effect was somewhat similar to that of reducing presynaptic $\mathrm{Ca}^{2+}$ entry by baclofen (Telgkamp et al., 2004), indicating that the increased AP failures in multiple axons by $\mathrm{BK}$ channel inhibition resulted in the reduction of presynaptic $\mathrm{Ca}^{2+}$ influx in some presynaptic boutons. These results suggest that BK channels specifically localized to paranodes of Purkinje cell axons regulate axonal APs and the final output of the cerebellar cortex to the cerebellar nuclei.

\section{Discussion}

Purkinje cells are the sole output of the cerebellar cortex. To understand information processing in the cerebellar circuit, it is important to understand the mechanisms regulating APs in their myelinated axons. Here, we described a new regulatory mechanism by paranodal BK channels for high-frequency and highfidelity axonal AP propagation. This novel paranodal localization of BK channels was confirmed by two distinct mouse mAbs, indicating that the labeling is genuine and that the specific localization at Purkinje cell paranodes is not attributable to epitope masking preventing labeling of BK channels at other sites. Because the effect of BK channel blockers was observed on axonal APs in virtually all Purkinje cells analyzed (for an example, see Fig. 6D) and on the integrated synaptic output (Fig. 8), the majority of Purkinje cell axons are likely to express BK channels. Although several different $\mathrm{K}^{+}$channels have been found at the node of Ranvier and in the juxtaparanodal region (Rasband and Shrager, 2000; Devaux et al., 2003; Pan et al., 2006; Trimmer, 
A

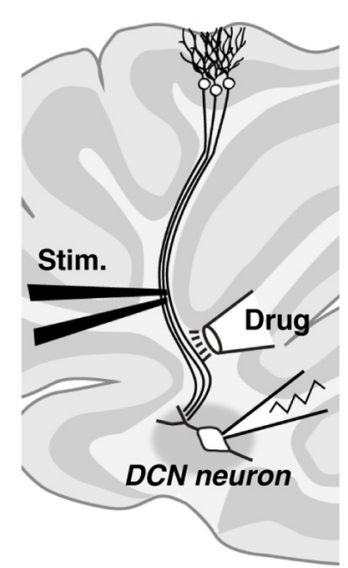

B

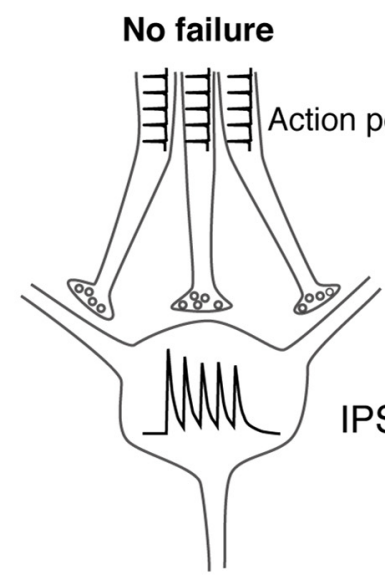

C Occasional failures

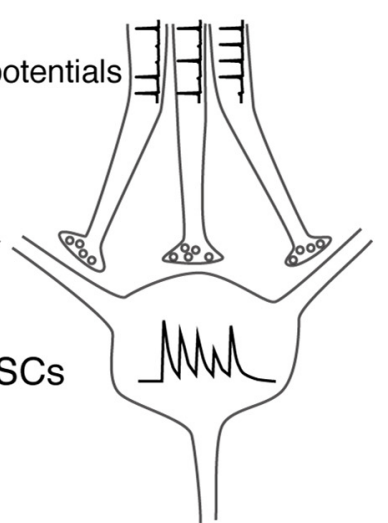

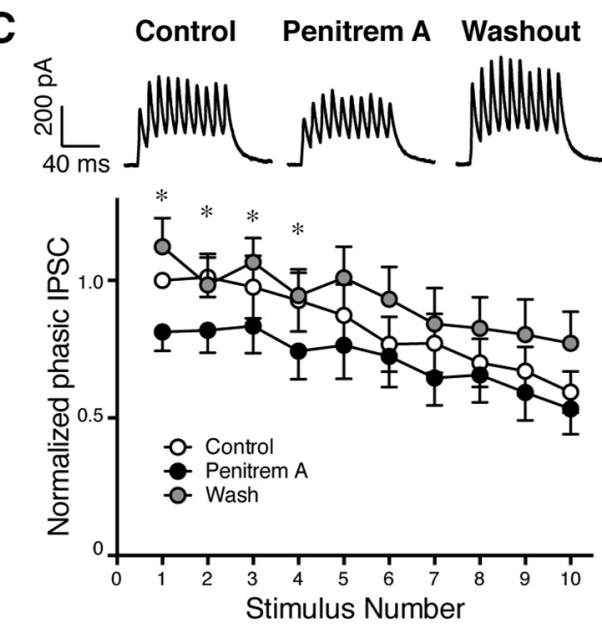

Figure 8. Reduction of IPSC amplitude in DCNs by local application of penitrem A to Purkinje cell axons. $A$, Schematic diagram showing the experimental setup. $\boldsymbol{B}$, Prediction of the effect of penitrem A. Blocking axonal BK channels would augment the propensity of failures of APs in the axon. Because single DCN neurons receive inputs from multiple Purkinje cell axons, occasional failures of axonal APs would translate to a reduction of the amplitude of IPSCs rather than their failures. C, IPSCs recorded from DCN neurons before (Control) and after the application of penitrem A to the white matter away from DCNs. Values were normalized to the first phasic IPSC in control. The blocker significantly reduced the overall amplitude of IPSCs evoked at $100 \mathrm{~Hz}$. IPSCs recovered after a 5 min washout $(p=0.05$ with 2-way ANOVA between Control and Penitrem $A, n=10) .{ }^{*} p<0.05$ with post hoc analysis between Control and Penitrem A.

2015), this is the first example of a $\mathrm{K}^{+}$channel in the paranode. Paranodal BK channels may have been overlooked because they appear to be present only in Purkinje cell axons.

Paranodes are organized by cell-adhesion molecules at the axon-glia junction, which functions not only to electrically isolate internodal membranes from nodal membranes but also to limit the lateral diffusion of ion channels in the axonal membrane (Chang and Rasband, 2013). Among the cell-adhesion molecules, Caspr is critical in forming these paranodal structures (Gollan et al., 2003), and loss of Caspr results in mislocalization of juxtaparanodal Kv1 channels (Bhat et al., 2001). In this study, we found that the paranodal localization of BK channels was disrupted in Caspr-deficient mice. Therefore, the paranodal localization of BK channels in Purkinje cell axons depends on a paranodal junction-dependent mechanism, although the precise molecular mechanism that clusters paranodal BK channels specifically in Purkinje cells remains to be elucidated. Interestingly, mice with disrupted paranodal junctions have preferential degeneration of Purkinje cell axons (GarciaFresco et al., 2006). Loss of paranodal BK channels may contribute to this Purkinje cell-specific axon degeneration through excitoxic mechanisms.

Using specific BK channel blockers, we also provide evidence that paranodal BK channels support high-frequency axonal AP firing. To investigate the role of paranodal BK channels, we recorded antidromic APs evoked in the axon. These antidromic APs exhibited substantial failures above a $100 \mathrm{~Hz}$ firing rate. The fidelity of antidromic APs in our experiments is low compared with those reported in previous studies using mouse cerebellar slices, in which virtually no axonal AP failures were observed at firing rates up to $200 \mathrm{~Hz}$ (Khaliq and Raman, 2005, 2006; Monsivais et al., 2005). This may reflect differences in the age of animals used (juvenile in previous studies vs young adults in this study) and/or the recording temperature. Alternatively, the extracellular stimulation of the myelinated axons in our experiments might have occasionally failed to evoke APs. Nevertheless, the significant increase in the failure rate of antidromic APs observed after treatment with the BK channel blockers strongly suggests that paranodal BK channels play pivotal roles in regulating axonal APs in Purkinje cells.
We observed increased AP failures with two membranepermeable BK channel blockers, paxilline and penitrem $\mathrm{A}$, but not with membrane-impermeable iberiotoxin. Although we attribute the lack of effect of iberiotoxin to its limited accessibility to paranodal BK channels, it is also possible that iberiotoxininsensitive BK channels dominate the paranodal region, as is the case with BK channels in the Purkinje cell somata (Benton et al., 2013). It was also necessary to use the membrane-permeable BK channel blockers at relatively high concentrations to observe changes in the antidromic APs within several minutes. We speculate that this reflects the fact that the BK channels at paranodes are covered with glial membranes and that these lipophilic blockers may be absorbed by these membranes and restricted from effectively reaching the $\mathrm{BK}$ channels. The result that two different and structurally dissimilar BK channel blockers, paxilline and penitrem $A$, both elicited a similar increase in the failure rate suggests that the effect results from specific inhibition of axonal BK channels.

To further generalize our findings to orthodromic APs, we also investigated the effects of BK channel blockers, as applied locally to Purkinje cell axons, on the inhibitory synaptic transmission between Purkinje cells and DCN neurons. We predicted that, as BK channel blockers increase the failure of orthodromic APs, synaptic transmission would be suppressed. In fact, we observed a significant reduction of IPSC amplitude after focally blocking axonal BK channels. Together, our results suggest that axonal BK channels support high-frequency and high-fidelity firing of APs and their conduction in the myelinated axon of Purkinje cells, thereby ensuring the output of the cerebellar cortex.

How does the BK channel support high-fidelity firing in the axon? BK channels have rapid activation and deactivation kinetics (Cui et al., 1997), which allow them to contribute to AHPs in Purkinje cell somata (Womack and Khodakhah, 2002; Edgerton and Reinhart, 2003; Swensen and Bean, 2003), in which an increase of $\left[\mathrm{Ca}^{2+}\right]_{\mathrm{i}}$ in response to a single AP is sufficient to activate somatic BK channels. Inhibition of somatic BK channels in Purkinje cells reduces AHPs and yields increased AP firing (Edgerton and Reinhart, 2003; Swensen and Bean, 2003; Womack et al., 2009), presumably because of increased membrane depolarization after each AP. Therefore, if paranodal BK channels serve a 
similar role in the axon, BK channel inhibition would cause increased axonal AP firing. However, the inhibition of axonal BK channels decreased the firing of antidromic APs by increasing the failure rate. In addition to nodal $\mathrm{K}^{+}$channels (Devaux et al., 2003; Pan et al., 2006), large-conductance paranodal BK channels might be critical to repolarize the nodal membrane to recover Nav channels during high-frequency firing. In this scenario, inhibition of axonal BK channels would cause a slightly more depolarized nodal membrane potentials after each AP, thereby slowing the recovery of $\mathrm{Nav}$ channels from inactivation and thus reducing the availability of nodal Nav channels, resulting in an increased failure rate (Yang and Wang, 2013). This is generally consistent with the higher firing rates seen in dentate granule cells in response to the gain of function for BK channels obtained in the BK- $\beta 4$ subunit knock-out mouse (Brenner et al., 2005). Moreover, that BK channels located at different sites in the same neuron can generate bidirectional effects on neuronal firing under distinct conditions is consistent with complex roles for BK channels in regulating excitability (Montgomery and Meredith, 2012). Future modeling studies may help clarify the ionic mechanism whereby paranodal BK channels support axonal APs in Purkinje cells.

$\mathrm{BK}$ channels generally require $\mathrm{Ca}^{2+}$ for their activation by physiological membrane potentials (Barrett et al., 1982), and a recent report argues that $\mathrm{Ca}^{2+}$ is the primary determinant of $\mathrm{BK}$ channel activation (Berkefeld and Fakler, 2013). However, there exist distinct BK channel splicing isoforms, auxiliary subunits, and interacting proteins that yield BK channels activated solely by physiological membrane depolarization (Chen et al., 2005; Yan and Aldrich, 2010). Therefore, it is possible that paranodal BK channels do not require $\mathrm{Ca}^{2+}$. Although highly localized increases in $\mathrm{Ca}^{2+}$ have been observed at nodes of Ranvier of certain axons (Zhang et al., 2010), more uniform $\mathrm{Ca}^{2+}$ transients are seen in others (Zhang et al., 2006). We found that the broadspectrum Cav channel blocker $\mathrm{Ni}^{2+}$ showed an effect similar to BK channel blockers in increasing the failure of antidromic APs. These results suggest that $\mathrm{R}$ - and T-type $\mathrm{Ni}^{2+}$-sensitive Cav channels contribute to the regulation of axonal APs. This may be consistent with the finding that $\mathrm{Ni}^{2+}$-sensitive Cav channels are expressed in the axon initial segment of Purkinje cells (Bender and Trussell, 2009), because the nodal region often expresses a similar repertoire of ion channels as found in the initial segment (Chang and Rasband, 2013). Although the effects of $\mathrm{Ni}^{2+}$, as well as $\mathrm{Ca}^{2+}$-free ACSF, might be mediated by other $\mathrm{Ca}^{2+}$-sensitive $\mathrm{K}^{+}$channels or $\mathrm{Ca}^{2+}$-dependent processes, given the similar effect to BK blockers, we speculate that Cav channels supply $\mathrm{Ca}^{2+}$ to paranodal BK channels and thereby contribute to the repolarization of Purkinje cell axon nodal membranes.

In summary, the results described here demonstrate that paranodal BK channels regulate the function of Purkinje cell axons. The regulation of individual axons by paranodal BK channels also affects the synaptic transmission of Purkinje cells to DCNs, the final output of the cerebellar cortex. Because we did not find paranodal BK channels outside of the cerebellum, we speculate that these paranodal BK channels may be a molecular specialization unique to the Purkinje cell axon, which confers on them unique axonal physiology. Furthermore, the implication that Cav channels are involved in regulating axonal APs suggests that other $\mathrm{Ca}^{2+}$-dependent processes may operate in myelinated axons to influence plasticity of axonal AP conduction in Purkinje cells. The results presented here may contribute to a deeper understanding of the role of axonal $\mathrm{Ca}^{2+}$ in information processing and cerebellar dysfunction.

\section{References}

Barrett JN, Magleby KL, Pallotta BS (1982) Properties of single calciumactivated potassium channels in cultured rat muscle. J Physiol 331:211230. CrossRef Medline

Bender KJ, Trussell LO (2009) Axon initial segment Ca2 + channels influence action potential generation and timing. Neuron 61:259-271. CrossRef Medline

Benton MD, Lewis AH, Bant JS, Raman IM (2013) Iberiotoxin-sensitive and -insensitive BK currents in Purkinje neuron somata. J Neurophysiol 109: 2528-2541. CrossRef Medline

Berkefeld H, Fakler B (2013) Ligand-gating by $\mathrm{Ca}^{2+}$ is rate limiting for physiological operation of BK(Ca) channels. J Neurosci 33:7358-7367. CrossRef Medline

Berkefeld H, Sailer CA, Bildl W, Rohde V, Thumfart JO, Eble S, Klugbauer N, Reisinger E, Bischofberger J, Oliver D, Knaus HG, Schulte U, Fakler B (2006) BKCa-Cav channel complexes mediate rapid and localized Ca2+-activated K+ signaling. Science 314:615-620. CrossRef Medline

Bhat MA, Rios JC, Lu Y, Garcia-Fresco GP, Ching W, St Martin M, Li J, Einheber S, Chesler M, Rosenbluth J, Salzer JL, Bellen HJ (2001) Axonglia interactions and the domain organization of myelinated axons requires neurexin IV/Caspr/Paranodin. Neuron 30:369-383. CrossRef Medline

Brenner R, Chen QH, Vilaythong A, Toney GM, Noebels JL, Aldrich RW (2005) BK channel beta4 subunit reduces dentate gyrus excitability and protects against temporal lobe seizures. Nat Neurosci 8:1752-1759. CrossRef Medline

Bucher D, Goaillard JM (2011) Beyond faithful conduction: short-term dynamics, neuromodulation, and long-term regulation of spike propagation in the axon. Prog Neurobiol 94:307-346. CrossRef Medline

Callewaert G, Eilers J, Konnerth A (1996) Axonal calcium entry during fast "sodium" action potentials in rat cerebellar Purkinje neurones. J Physiol 495:641-647. CrossRef Medline

Chang KJ, Rasband MN (2013) Excitable domains of myelinated nerves: axon initial segments and nodes of Ranvier. Curr Top Membr 72:159192. CrossRef Medline

Chen L, Tian L, MacDonald SH, McClafferty H, Hammond MS, Huibant JM, Ruth P, Knaus HG, Shipston MJ (2005) Functionally diverse complement of large conductance calcium- and voltage-activated potassium channel (BK) alpha-subunits generated from a single site of splicing. J Biol Chem 280:33599-33609. CrossRef Medline

Clark BA, Monsivais P, Branco T, London M, Häusser M (2005) The site of action potential initiation in cerebellar Purkinje neurons. Nat Neurosci 8:137-139. CrossRef Medline

Cui J, Cox DH, Aldrich RW (1997) Intrinsic voltage dependence and Ca2+ regulation of mslo large conductance Ca-activated $\mathrm{K}+$ channels. J Gen Physiol 109:647-673. CrossRef Medline

Davis JQ, Lambert S, Bennett V (1996) Molecular composition of the node of Ranvier: identification of ankyrin-binding cell adhesion molecules neurofascin (mucin +/third FNIII domain - ) and NrCAM at nodal axon segments. J Cell Biol 135:1355-1367. CrossRef Medline

Debanne D, Campanac E, Bialowas A, Carlier E, Alcaraz G (2011) Axon physiology. Physiol Rev 91:555-602. CrossRef Medline

Devaux J, Alcaraz G, Grinspan J, Bennett V, Joho R, Crest M, Scherer SS (2003) Kv3.1b is a novel component of CNS nodes. J Neurosci 23:45094518. Medline

Edgerton JR, Reinhart PH (2003) Distinct contributions of small and large conductance $\mathrm{Ca} 2+$-activated $\mathrm{K}+$ channels to rat Purkinje neuron function. J Physiol 548:53-69. CrossRef Medline

Einheber S, Zanazzi G, Ching W, Scherer S, Milner TA, Peles E, Salzer JL $(1997)$ The axonal membrane protein Caspr, a homologue of neurexin IV, is a component of the septate-like paranodal junctions that assemble during myelination. J Cell Biol 139:1495-1506. CrossRef Medline

Faber ES, Sah P (2003) Calcium-activated potassium channels: multiple contributions to neuronal function. Neuroscientist 9:181-194. CrossRef Medline

Galvez A, Gimenez-Gallego G, Reuben JP, Roy-Contancin L, Feigenbaum P, Kaczorowski GJ, Garcia ML (1990) Purification and characterization of a unique, potent, peptidyl probe for the high conductance calciumactivated potassium channel from venom of the scorpion Buthus tamulus. J Biol Chem 265:11083-11090. Medline

Garcia-Fresco GP, Sousa AD, Pillai AM, Moy SS, Crawley JN, Tessarollo L, Dupree JL, Bhat MA (2006) Disruption of axo-glial junctions causes 
cytoskeletal disorganization and degeneration of Purkinje neuron axons. Proc Natl Acad Sci U S A 103:5137-5142. CrossRef Medline

Gollan L, Salomon D, Salzer JL, Peles E (2003) Caspr regulates the processing of contactin and inhibits its binding to neurofascin. J Cell Biol 163: 1213-1218. CrossRef Medline

Grunnet M, Kaufmann WA (2004) Coassembly of big conductance Ca2 +activated $\mathrm{K}+$ channels and L-type voltage-gated $\mathrm{Ca} 2+$ channels in rat brain. J Biol Chem 279:36445-36453. CrossRef Medline

Hermanstyne TO, Kihira Y, Misono K, Deitchler A, Yanagawa Y, Misonou H (2010) Immunolocalization of the voltage-gated potassium channel Kv2.2 in GABAergic neurons in the basal forebrain of rats and mice. J Comp Neurol 518:4298-4310. CrossRef Medline

Hirono M, Saitow F, Kudo M, Suzuki H, Yanagawa Y, Yamada M, Nagao S, Konishi S, Obata K (2012) Cerebellar globular cells receive monoaminergic excitation and monosynaptic inhibition from Purkinje cells. PLoS One 7:e29663. CrossRef Medline

Jeffries O, Geiger N, Rowe IC, Tian L, McClafferty H, Chen L, Bi D, Knaus HG, Ruth P, Shipston MJ (2010) Palmitoylation of the S0-S1 linker regulates cell surface expression of voltage- and calcium-activated potassium (BK) channels. J Biol Chem 285:33307-33314. CrossRef Medline

Khaliq ZM, Raman IM (2005) Axonal propagation of simple and complex spikes in cerebellar Purkinje neurons. J Neurosci 25:454-463. CrossRef Medline

Khaliq ZM, Raman IM (2006) Relative contributions of axonal and somatic $\mathrm{Na}$ channels to action potential initiation in cerebellar Purkinje neurons. J Neurosci 26:1935-1944. CrossRef Medline

Knaus HG, McManus OB, Lee SH, Schmalhofer WA, Garcia-Calvo M, Helms LM, Sanchez M, Giangiacomo K, Reuben JP, Smith AB 3rd, Kaczorowski GJ, Garcia ML (1994) Tremorgenic indole alkaloids potently inhibit smooth muscle high-conductance calcium-activated potassium channels. Biochemistry 33:5819-5828. CrossRef Medline

Kocsis JD, Waxman SG (1980) Absence of potassium conductance in central myelinated axons. Nature 287:348-349. CrossRef Medline

Lai HC, Jan LY (2006) The distribution and targeting of neuronal voltagegated ion channels. Nat Rev Neurosci 7:548-562. CrossRef Medline

Levental I, Lingwood D, Grzybek M, Coskun U, Simons K (2010) Palmitoylation regulates raft affinity for the majority of integral raft proteins. Proc Natl Acad Sci U S A 107:22050-22054. CrossRef Medline

Lev-Ram V, Ellisman MH (1995) Axonal activation-induced calcium transients in myelinating Schwann cells, sources, and mechanisms. J Neurosci 15:2628-2637. Medline

Liu G, Shi J, Yang L, Cao L, Park SM, Cui J, Marx SO (2004) Assembly of a $\mathrm{Ca} 2+$-dependent $\mathrm{BK}$ channel signaling complex by binding to beta2 adrenergic receptor. EMBO J 23:2196-2205. CrossRef Medline

Meera P, Wallner M, Song M, Toro L (1997) Large conductance voltageand calcium-dependent $\mathrm{K}+$ channel, a distinct member of voltagedependent ion channels with seven $\mathrm{N}$-terminal transmembrane segments (S0-S6), an extracellular $\mathrm{N}$ terminus, and an intracellular (S9-S10) C terminus. Proc Natl Acad Sci U S A 94:14066-14071. CrossRef Medline

Menegoz M, Gaspar P, Le Bert M, Galvez T, Burgaya F, Palfrey C, Ezan P, Arnos F, Girault JA (1997) Paranodin, a glycoprotein of neuronal paranodal membranes. Neuron 19:319-331. CrossRef Medline

Mierzwa A, Shroff S, Rosenbluth J (2010) Permeability of the paranodal junction of myelinated nerve fibers. J Neurosci 30:15962-15968. CrossRef Medline

Misonou H, Mohapatra DP, Menegola M, Trimmer JS (2005) Calcium- and metabolic state-dependent modulation of the voltage-dependent Kv2.1 channel regulates neuronal excitability in response to ischemia. J Neurosci 25:11184-11193. CrossRef Medline

Misonou H, Menegola M, Buchwalder L, Park EW, Meredith A, Rhodes KJ, Aldrich RW, Trimmer JS (2006) Immunolocalization of the $\mathrm{Ca}(2+)$ activated $\mathrm{K}(+)$ channel Slo1 in axons and nerve terminals of mammalian brain and cultured neurons. J Comp Neurol 496:289-302. CrossRef Medline

Monsivais P, Clark BA, Roth A, Häusser M (2005) Determinants of action potential propagation in cerebellar Purkinje cell axons. J Neurosci 25: 464-472. CrossRef Medline

Montgomery JR, Meredith AL (2012) Genetic activation of BK currents in vivo generates bidirectional effects on neuronal excitability. Proc Natl Acad Sci U S A 109:18997-19002. CrossRef Medline

Ogawa Y, Schafer DP, Horresh I, Bar V, Hales K, Yang Y, Susuki K, Peles E, Stankewich MC, Rasband MN (2006) Spectrins and ankyrinB constitute a specialized paranodal cytoskeleton. J Neurosci 26:5230-5239. CrossRef Medline

Palkovits M, Magyar P, Szentágothai J (1972) Quantitative histological analysis of the cerebellar cortex in the cat. IV. Mossy fiber-Purkinje cell numerical transfer. Brain Res 45:15-29. CrossRef Medline

Pan Z, Kao T, Horvath Z, Lemos J, Sul JY, Cranstoun SD, Bennett V, Scherer SS, Cooper EC (2006) A common ankyrin-G-based mechanism retains KCNQ and $\mathrm{NaV}$ channels at electrically active domains of the axon. J Neurosci 26:2599-2613. CrossRef Medline

Poliak S, Peles E (2003) The local differentiation of myelinated axons at nodes of Ranvier. Nat Rev Neurosci 4:968-980. CrossRef Medline

Rasband, MN (2004) It's "juxta” potassium channel! J Neurosci Res 76:749-757.

Rasband MN, Shrager P (2000) Ion channel sequestration in central nervous system axons. J Physiol 525:63-73. CrossRef Medline

Rasband MN, Trimmer JS, Schwarz TL, Levinson SR, Ellisman MH, Schachner M, Shrager P (1998) Potassium channel distribution, clustering, and function in remyelinating rat axons. J Neurosci 18:36-47. Medline

Rhodes KJ, Strassle BW, Monaghan MM, Bekele-Arcuri Z, Matos MF, Trimmer JS (1997) Association and colocalization of the Kvbetal and Kvbeta2 beta-subunits with $\mathrm{Kv} 1$ alpha-subunits in mammalian brain $\mathrm{K}+$ channel complexes. J Neurosci 17:8246-8258. Medline

Salkoff L, Butler A, Ferreira G, Santi C, Wei A (2006) High-conductance potassium channels of the SLO family. Nat Rev Neurosci 7:921-931. CrossRef Medline

Sargoy A, Sun X, Barnes S, Brecha NC (2014) Differential calcium signaling mediated by voltage-gated calcium channels in rat retinal ganglion cells and their unmyelinated axons. PLoS One 9:e84507. CrossRef Medline

Sausbier M, Hu H, Arntz C, Feil S, Kamm S, Adelsberger H, Sausbier U, Sailer CA, Feil R, Hofmann F, Korth M, Shipston MJ, Knaus HG, Wolfer DP, Pedroarena CM, Storm JF, Ruth P (2004) Cerebellar ataxia and Purkinje cell dysfunction caused by $\mathrm{Ca} 2+$-activated $\mathrm{K}+$ channel deficiency. Proc Natl Acad Sci U S A 101:9474-9478. CrossRef Medline

Sausbier U, Sausbier M, Sailer CA, Arntz C, Knaus HG, Neuhuber W, Ruth P (2006) $\mathrm{Ca} 2+$-activated $\mathrm{K}+$ channels of the BK-type in the mouse brain. Histochem Cell Biol 125:725-741. CrossRef Medline

Schafer DP, Bansal R, Hedstrom KL, Pfeiffer SE, Rasband MN (2004) Does paranode formation and maintenance require partitioning of neurofascin 155 into lipid rafts? J Neurosci 24:3176-3185. CrossRef Medline

Schwarz JR, Glassmeier G, Cooper EC, Kao TC, Nodera H, Tabuena D, Kaji R, Bostock H (2006) KCNQ channels mediate IKs, a slow K+ current regulating excitability in the rat node of Ranvier. J Physiol 573:17-34. CrossRef Medline

Swensen AM, Bean BP (2003) Ionic mechanisms of burst firing in dissociated Purkinje neurons. J Neurosci 23:9650-9663. Medline

Telgkamp P, Raman IM (2002) Depression of inhibitory synaptic transmission between Purkinje cells and neurons of the cerebellar nuclei. J Neurosci 22:8447-8457. Medline

Telgkamp P, Padgett DE, Ledoux VA, Woolley CS, Raman IM (2004) Maintenance of high-frequency transmission at purkinje to cerebellar nuclear synapses by spillover from boutons with multiple release sites. Neuron 41:113-126. CrossRef Medline

Trimmer JS (2015) Subcellular localization of K channels in mammalian brain neurons: remarkable precision in the midst of extraordinary complexity. Neuron 85:238-256. CrossRef Medline

Tsantoulas C, Farmer C, Machado P, Baba K, McMahon SB, Raouf R (2013) Probing functional properties of nociceptive axons using a microfluidic culture system. PLoS One 8:e80722. CrossRef Medline

Tsien RW, Lipscombe D, Madison DV, Bley KR, Fox AP (1988) Multiple types of neuronal calcium channels and their selective modulation. Trends Neurosci 11:431-438. CrossRef Medline

Uusisaari M, Obata K, Knöpfel T (2007) Morphological and electrophysiological properties of GABAergic and non-GABAergic cells in the deep cerebellar nuclei. J Neurophysiol 97:901-911. CrossRef Medline

Vacher H, Mohapatra DP, Trimmer JS (2008) Localization and targeting of voltage-dependent ion channels in mammalian central neurons. Physiol Rev 88:1407-1447. CrossRef Medline

Wang H, Kunkel DD, Martin TM, Schwartzkroin PA, Tempel BL (1993) Heteromultimeric $\mathrm{K}+$ channels in terminal and juxtaparanodal regions of neurons. Nature 365:75-79. CrossRef Medline

Womack MD, Khodakhah K (2002) Characterization of large conductance 
$\mathrm{Ca} 2+$-activated $\mathrm{K}+$ channels in cerebellar Purkinje neurons. Eur J Neurosci 16:1214-1222. CrossRef Medline

Womack MD, Khodakhah K (2004) Dendritic control of spontaneous bursting in cerebellar Purkinje cells. J Neurosci 24:3511-3521. CrossRef Medline

Womack MD, Hoang C, Khodakhah K (2009) Large conductance calciumactivated potassium channels affect both spontaneous firing and intracellular calcium concentration in cerebellar Purkinje neurons. Neuroscience 162:989-1000. CrossRef Medline

Yan J, Aldrich RW (2010) LRRC26 auxiliary protein allows BK channel activation at resting voltage without calcium. Nature 466:513-516. CrossRef Medline

Yang Y, Lacas-Gervais S, Morest DK, Solimena M, Rasband MN (2004) Be-
taIV spectrins are essential for membrane stability and the molecular organization of nodes of Ranvier. J Neurosci 24:7230-7240. CrossRef Medline

Yang Z, Wang JH (2013) Frequency-dependent reliability of spike propagation is function of axonal voltage-gated sodium channels in cerebellar Purkinje cells. Cerebellum 12:862-869. CrossRef Medline

Zhang CL, Wilson JA, Williams J, Chiu SY (2006) Action potentials induce uniform calcium influx in mammalian myelinated optic nerves. J Neurophysiol 96:695-709. CrossRef Medline

Zhang CL, Ho PL, Kintner DB, Sun D, Chiu SY (2010) Activity-dependent regulation of mitochondrial motility by calcium and $\mathrm{Na} / \mathrm{K}$-ATPase at nodes of Ranvier of myelinated nerves. J Neurosci 30:3555-3566. CrossRef Medline 